Prepared in cooperation with the New Hampshire Department of Transportation

\title{
Flood Study of Warren Brook in Alstead and Cold River in Alstead, Langdon, and Walpole, New Hampshire, 2005
}

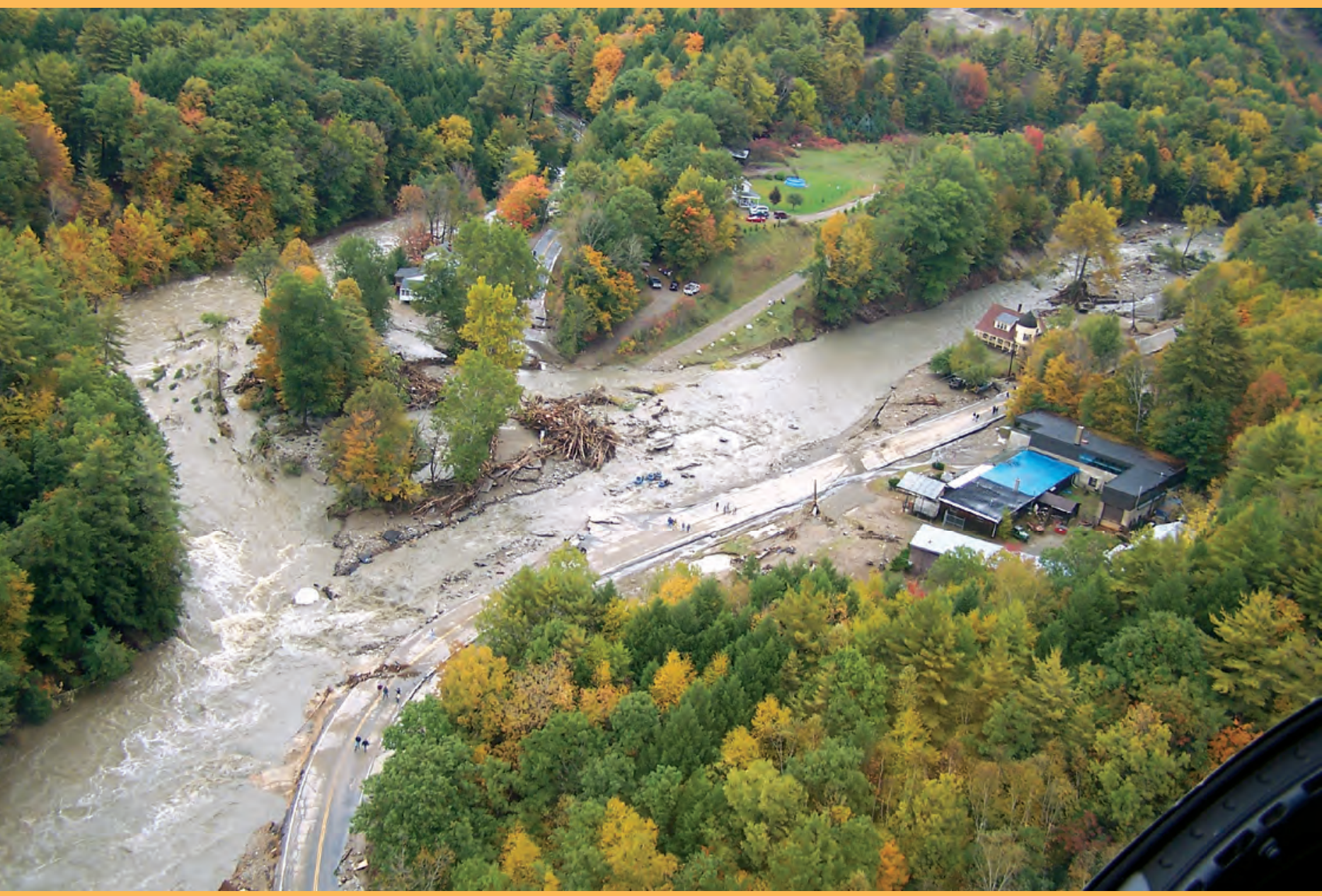

Open-File Report 2006-1313

U.S. Department of the Interior

U.S. Geological Survey 
Cover. Photograph shows the confluence of Warren Brook (right) and Cold River (left) during the 0ctober 8-9, 2005 flood. (Photograph courtesy of the New Hampshire State Police Aviation Unit) 


\section{Flood Study of Warren Brook in Alstead and Cold River in Alstead, Langdon, and Walpole, New Hampshire, 2005}

By Robert H. Flynn

Prepared in cooperation with the New Hampshire Department of Transportation

Open-File Report 2006-1313 


\title{
U.S. Department of the Interior DIRK KEMPTHORNE, Secretary
}

\author{
U.S. Geological Survey \\ Mark D. Myers, Director
}

U.S. Geological Survey, Reston, Virginia: 2006

For more information on the USGS — the Federal source for science about the Earth, its natural and living resources, natural hazards, and the environment:

World Wide Web: http://www.usgs.gov

Telephone: 1-888-ASK-USGS

Any use of trade, product, or firm names is for descriptive purposes only and does not imply endorsement by the U.S. Government.

Although this report is in the public domain, permission must be secured from the individual copyright owners to reproduce any copyrighted materials contained within this report.

Suggested citation:

Flynn, R.H., 2006, Flood study of Warren Brook in Alstead and Cold River in Alstead, Langdon, and Walpole, New Hampshire, 2005: U.S. Geological Survey Open-File Report 2006-1313, 48 p. 


\section{Contents}

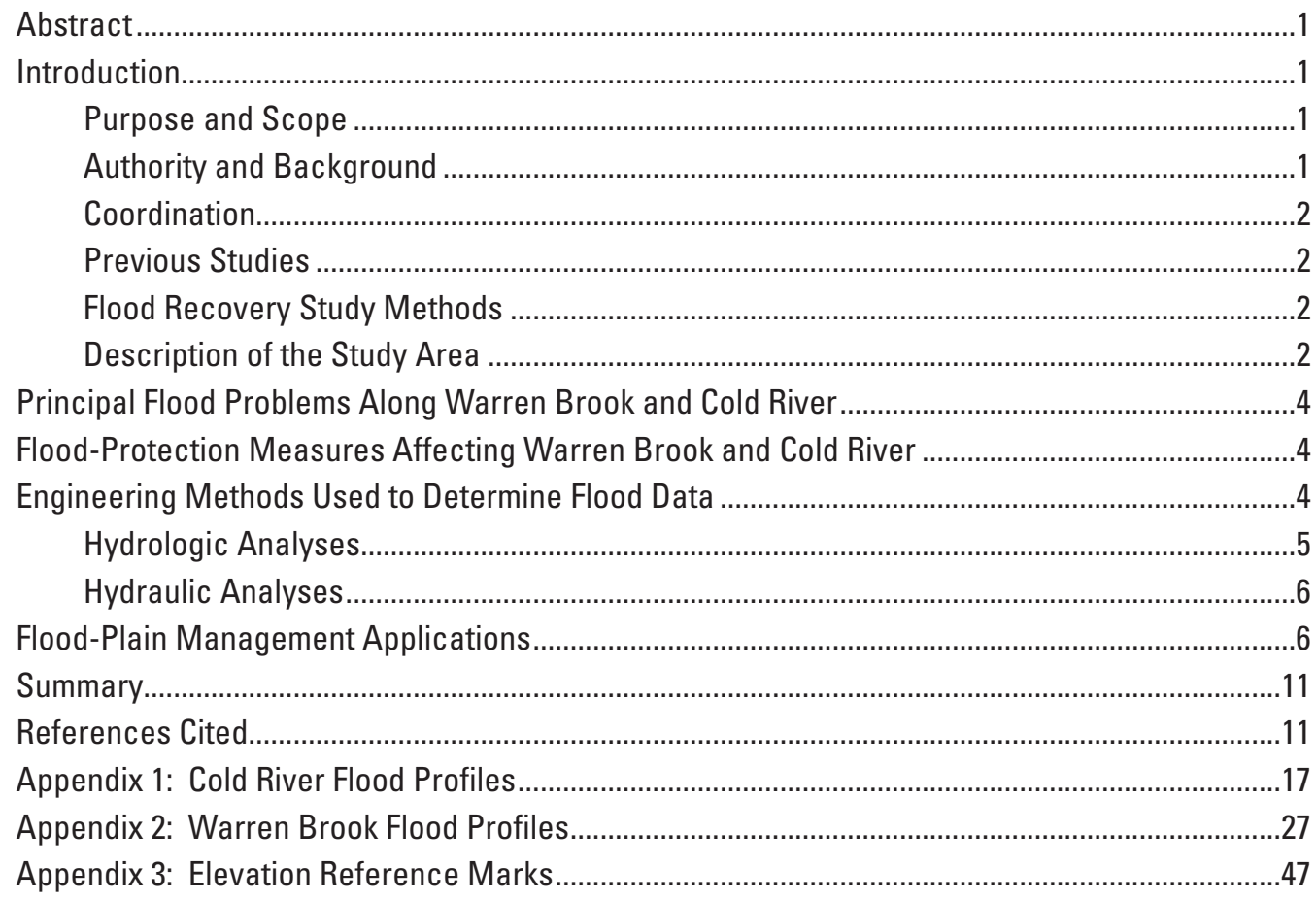

\section{Figures}

\section{1-5. Maps showing-}

1. Extent of the flood insurance study of Cold River and Warren Brook in Alstead, Langdon, and Walpole, New Hampshire ......................................................

2. Location of cross sections along Cold River in Walpole and Langdon, New Hampshire

3. Location of cross sections along Cold River in Alstead and Langdon, New Hampshire .................................................................................................

4. Location of cross sections along Warren Brook in Alstead, New Hampshire........14

5. Location of cross sections along Warren Brook in Alstead, New Hampshire........15

\section{Tables}

1. Summary of the drainage area-peak relations for streams in New Hampshire,

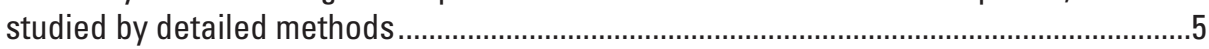

2. Manning's " $n$ " values for Cold River and Warren Brook .................................................

3. Cross sections and flood data for Cold River in Alstead, Langdon, and Walpole, New Hampshire.................................................................................................

4. Cross sections and flood data for Warren Brook in Alstead, New Hampshire..................9 


\section{Conversion Factors, Abbreviations, and Datum}

\begin{tabular}{lcl}
\hline \multicolumn{1}{c}{ Multiply } & By & \multicolumn{1}{c}{ To obtain } \\
\hline inch (in.) & Length & \\
inch (in.) & 2.54 & centimeter $(\mathrm{cm})$ \\
foot (ft) & 25.4 & millimeter $(\mathrm{mm})$ \\
mile (mi) & 0.3048 & meter $(\mathrm{m})$ \\
\hline & 1.609 & kilometer $(\mathrm{km})$ \\
\hline square mile $\left(\mathrm{mi}^{2}\right)$ & Area & \\
square mile $\left(\mathrm{mi}^{2}\right)$ & 259.0 & hectare $(\mathrm{ha})$ \\
square mile $\left(\mathrm{mi}^{2}\right)$ & 2.589 & square kilometer $\left(\mathrm{km}^{2}\right)$ \\
& 0.929 & square meter $\left(\mathrm{m}^{2}\right)$ \\
\hline cubic foot $\left(\mathrm{ft}^{3}\right)$ & Volume & \\
\hline & 0.02832 & cubic meter $\left(\mathrm{m}^{3}\right)$ \\
\hline foot per second (ft/s) & Flow rate & \\
cubic foot per second $\left(\mathrm{ft}^{3} / \mathrm{s}\right)$ & 0.3048 & meter per second $(\mathrm{m} / \mathrm{s})$ \\
\hline & 0.02832 & cubic meter per second $\left(\mathrm{m}^{3} / \mathrm{s}\right)$ \\
\hline foot per mile (ft/mi) & Hydraulic gradient & \\
\hline & 0.1894 & meter per kilometer $(\mathrm{m} / \mathrm{km})$ \\
\hline
\end{tabular}

Vertical coordinate information is referenced to the National Geodetic Vertical Datum of 1929 (NGVD 29).

Horizontal coordinate information is referenced to the North American Datum of 1983 (NAD 83).

OTHER ABBREVIATIONS USED IN REPORT

CCO Consultation Coordination Officer

FEMA Federal Emergency Management Agency

FIA Federal Insurance Administration

FIRM Flood Insurance Rate Map

FIS Flood Insurance Study

GIS Geographical Information System

HEC-RAS Hydrologic Engineering Center-River Analysis System

NH New Hampshire

NHDOT New Hampshire Department of Transportation

NFIP National Flood Insurance Program

NOAA National Oceanic and Atmospheric Administration

SFHA Special Flood Hazard Area

USACE U.S. Army Corps of Engineers

USGS U.S. Geological Survey 


\title{
Flood Study of Warren Brook in Alstead and Cold River in Alstead, Langdon, and Walpole, New Hampshire, 2005
}

\author{
By Robert H. Flynn
}

\section{Abstract}

This report presents water-surface elevations and profiles as determined using the U.S. Army Corps of Engineers (USACE) one-dimensional Hydrologic Engineering Center River Analysis System, also known as HEC-RAS. Steady flow water-surface profiles were developed for two stream reaches: the Cold River from its confluence with the Connecticut River in Walpole, through Alstead to the McDermott Bridge in Langdon, NH, and Warren Brook from its confluence with the Cold River to Warren Lake in Alstead, NH. Flood events of a magnitude, which are expected to be equaled or exceeded once on the average during any 10-, 50-, 100-, or 500-year period (recurrence interval), were modeled using HEC-RAS as these flood events are recognized as being significant for floodplain management, determination of flood insurance rates, and design of structures such as bridges and culverts. These flood events are referred to as the 10-, 50-, 100-, and 500-year floods and have a 10-, 2-, 1-, and 0.2-percent chance, respectively, of being equaled or exceeded during any year. The recurrence intervals represent the long-term average between floods of a specific magnitude. The risk of experiencing rare floods at short intervals or within the same year increases when periods greater than one year are considered. The analyses in this study reflect the flooding potentials based on conditions existing in the communities of Walpole, Alstead and Langdon at the time of completion of this study.

\section{Introduction}

On October 8 and 9, 2005, significant flooding occurred in southwestern New Hampshire $(\mathrm{NH})$ as a result of rainfall in excess of 7 in. within a 24-hour period. Unverified accounts stated that as much as $11 \mathrm{in}$. of rain fell in the Alstead, NH, area. The National Oceanic and Atmospheric Administration (NOAA) recorded 7.68 in. of rain during October 8-9, 2005, at the precipitation station in Keene, NH (National Weather Service, 2005). Upstream from Alstead, on Warren Brook, the failure of a culvert and a road embankment that was impounding a significant amount of floodwater also contributed to severe flooding along Warren Brook and downstream on the Cold River in Alstead, Langdon, and Walpole. The current effective Federal Emergency Management Agency (FEMA) Flood Insurance Rate Maps (FIRM) (Alstead, 1986; Langdon, 1975; and Walpole, 2000) contain both detailed and approximately determined 100year (Zone A) special-flood-hazard areas that are no longer considered valid. In order to guide redevelopment and the replacement of damaged infrastructure and the allocation of appropriate State and Federal recovery resources, and to ensure that effective mitigation measures are in place to avoid future flood losses, it is essential that reliable and timely information on flood elevations be established for these rivers.

\section{Purpose and Scope}

This recovery study report provides flood elevations for the Cold River and Warren Brook to aid in the redevelopment and the replacement of infrastructure damaged in the October 2005 flood and the allocation of appropriate State and Federal recovery resources, and to ensure that effective mitigation measures are in place to avoid future flood losses. The results of this study can also be used to update the previous flood insurance studies (FISs) and FIRMs for the towns of Alstead and Walpole, NH, and flood hazard boundary map for Langdon (Federal Emergency Management Agency, 1986, 2000,1975 , respectively). This information can be used to update existing flood-plain regulations as part of the National Flood Insurance Program (NFIP). The minimum flood-plain management requirements for participation in the NFIP are set forth in the Code of Federal Regulations at 44 CFR, 60.3. The information also can be used by local and regional planners to further promote sound land-use and flood-plain development.

\section{Authority and Background}

The sources of authority for a flood insurance study are the National Flood Insurance Act of 1968 and the Flood Disaster Protection Act of 1973. On October 26, 2005, President George W. Bush declared five counties in New Hampshire to be a major disaster area as a result of the flooding that occurred on October 8-9, 2005. For the 2005 FIS, the hydrologic and hydraulic analyses for the Cold River 
and Warren Brook were conducted by the U.S. Geological Survey (USGS) in cooperation with the New Hampshire Department of Transportation (NHDOT) under agreement number 06E4NH24500017. This work was completed in April 2006.

The hydrologic and hydraulic analyses from the 1980 FIS for the Cold River conducted by Environmental Engineers, Inc., for the Federal Insurance Administration (FIA) under contract number H-4590, were used for the May 4, 2000, FIS and FIRM for Walpole, NH. The 1980 FIS work was completed in October 1978. The FIS report was dated October 15, 1980, and the FIRM was dated April 15, 1981. The extent of the 1978 study along Cold River was limited to an approximately 1-mi reach above its confluence with the Connecticut River.

There are no FIS reports for the towns of Alstead and Langdon. For the original April 2, 1986, FIRM in Alstead, Zone A flood insurance rate zones were determined along Warren Brook and Cold River. Zone A is the flood insurance rate zone that corresponds to the 100-year flood-plain and is determined in a FIS by approximate methods. Because detailed hydraulic analyses are not performed for such areas, no base flood elevations or depths are shown within this zone. Langdon, NH, is not in FEMA's NFIP, but special flood hazard areas (SFHA) were identified along the Cold River in the FIRM dated January 3, 1975.

\section{Coordination}

At an initial Consultation Coordination Officer's (CCO) meeting on January 11, 2006, representatives of the NHDOT and the USGS discussed the scope of the FIS. Several meetings were held subsequently with the town of Alstead and representatives of various state agencies-on January 26, 2006 (at the Alstead town offices) and on February 1, 2006 (at the site of the former Kmiec's Garage, which is located at the intersection of Route 123 and Route 123A). On March 23, 2006, a New Hampshire Interagency Mitigation Meeting was held at the town library in Alstead.

\section{Previous Studies}

A FIS and FIRM was prepared for the town of Walpole in May 2000 (Federal Emergency Management Agency, 2000). At that time, there were no FIS reports for the towns of Alstead or Langdon. For the original April 2, 1986, FIRM in Alstead, Zone A flood insurance rate zones were determined along Warren Brook. Langdon is not included in the FEMA's NFIP, but SFHAs were identified along the Cold River in the FIRM dated January 3, 1975.

Because it is based on more up-to-date analyses, this FIS supersedes the previously printed flood study data for the towns of Walpole, Alstead, and Langdon on the Cold River and Warren Brook. This FIS also supersedes the flood boundary map for Cold River in the town of Walpole (published as part of the previously printed FIS), the Zone A flood insurance rate zones along Warren Brook and Cold River in Alstead and the SFHAs identified along the Cold River in Langdon, $\mathrm{NH}$.

\section{Flood Recovery Study Methods}

This flood recovery study includes the Cold River and Warren Brook in the incorporated area of the towns of Alstead and Walpole in Cheshire County, and the town of Langdon in Sullivan County, NH (fig. 1). The Cold River was studied by detailed methods from the confluence with the Connecticut River to the McDermott covered bridge in Langdon. Warren Brook was studied by detailed methods from the confluence with Cold River to Warren Lake. Limits of detailed study are indicated on the flood profiles (appendixes 1 and 2). The areas studied by detailed methods were selected with priority given to all known flood hazard areas as well as to areas of projected development and proposed construction. The scope and methods of study were proposed to, and agreed upon by the NHDOT, USGS, and the town of Alstead.

\section{Description of the Study Area}

The towns of Walpole and Alstead are located in northwestern Cheshire County, which is in southwestern New Hampshire (fig. 1). The town of Langdon is in southwestern Sullivan County, which also is in southwestern New Hampshire. State Route 123 connects the towns of Walpole, Langdon, and Alstead.

Walpole is on a mountain-bordered plateau that slopes to the south and west. Alstead and Langdon are located in the foothills and mountains to the east and northeast of Walpole and its plateau. Here, the Cold River bisects the remnants of a delta, which extends back to Cock Hat Hill (just south of Vilas Pool) east of the Alstead town center, and was formed in glacial Lake Hitchcock 10,000 years ago. Terraces on either side of the river reveal that the elevation of the top of the delta was at an elevation of $492 \mathrm{ft}$ (Cold River Local Advisory Committee, 2006). Most of the area is covered by glacial till, about two-thirds of which is derived principally from granitic rock and one-third from schistose rock. Soils developed on this till are naturally stony and, thus, most of the area is not suitable for large-scale agricultural activities, except in the broad floodplains of streams (Federal Emergency Management Agency, 2000).

The population of Alstead in 2004 was 2,019 residents (New Hampshire Employment Security, 2005a). Alstead contains $39.0 \mathrm{mi}^{2}$ of land area and $0.4 \mathrm{mi}^{2}$ of inland water area. There are 51.8 persons $/ \mathrm{mi}^{2}$ of land area in Alstead. The villages of Alstead Center, East Alstead, and Mill Hollow are all within the town of Alstead (New Hampshire Employment Security, 2005a). 


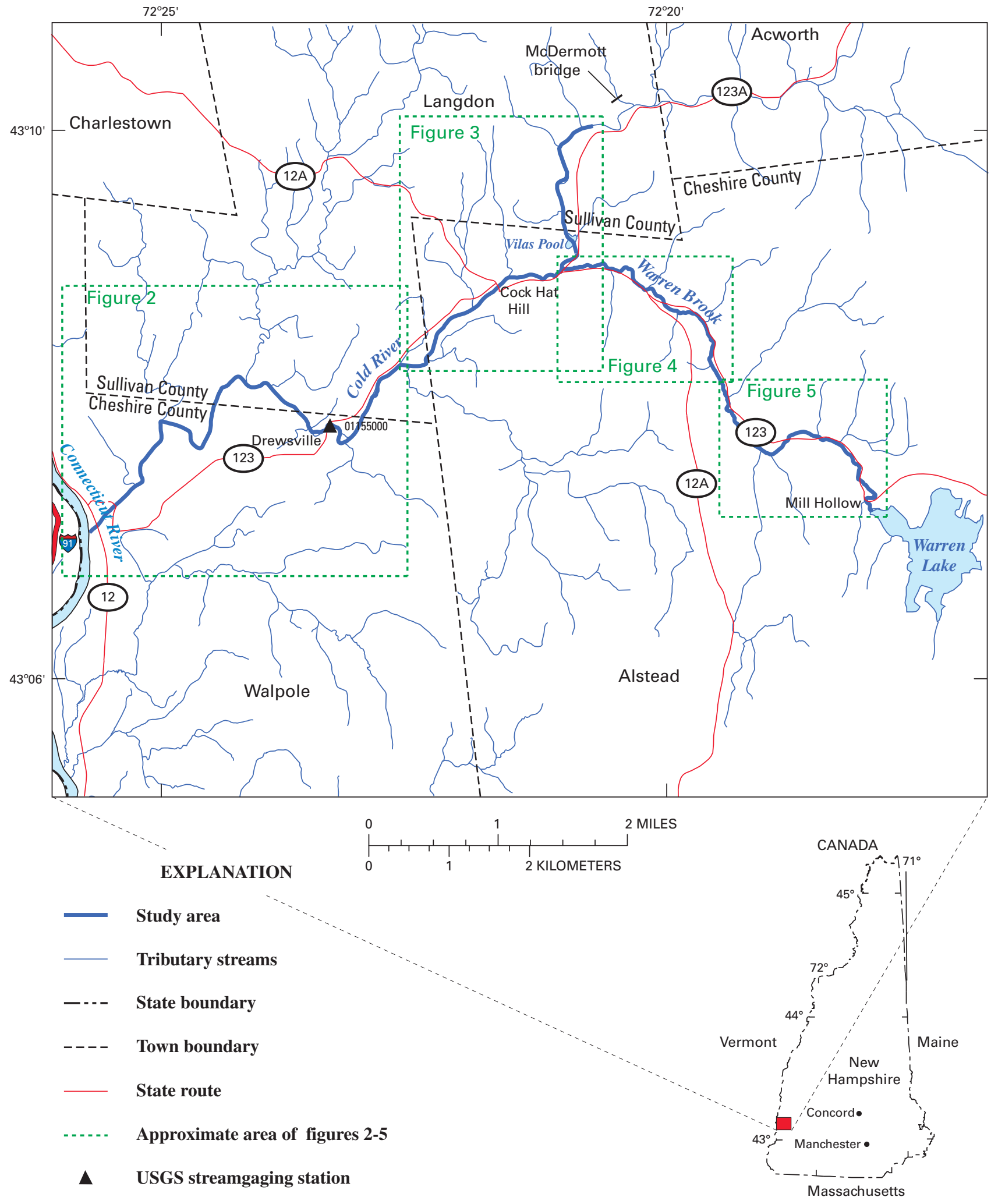

Figure 1. Extent of the flood insurance study of Cold River and Warren Brook in Alstead, Langdon, and Walpole, New Hampshire. 
The 2004 population of Langdon was 637 residents (New Hampshire Employment Security, 2005b). Langdon contains $16.3 \mathrm{mi}^{2}$ of land area and $0 \mathrm{mi}^{2}$ of inland water area. There are 39.1 persons $/ \mathrm{mi}^{2}$ of land area in Langdon. The villages of Cold River District and Condon Corner are within the town of Langdon (New Hampshire Employment Security, 2005b).

The 2004 population for Walpole was 3,704 residents (New Hampshire Employment Security, 2005c). Walpole contains $35.7 \mathrm{mi}^{2}$ of land area and $1.0 \mathrm{mi}^{2}$ of inland water area. There are 103.8 persons $/ \mathrm{mi}^{2}$ of land area in Walpole. The villages of Drewsville and North Walpole are within the Town of Walpole (New Hampshire Employment Security, 2005c).

\section{Principal Flood Problems Along Warren Brook and Cold River}

Major floods can occur on Warren Brook and Cold River during the spring, fall, and winter. Some of the most severe flooding occurs in early spring as a result of snow melt and heavy rains in conjunction with ice jams. Fall is another critical season for flood danger because of typically heavy rainfall and the possibility of tropical storms. Flooding can occur, however, at any time of the year. Large thunderstorms can result in rapid runoff and flooding in the downstream portions of small streams (Federal Emergency Management Agency, 2000).

Most flooding in the town of Walpole has been from the Connecticut River and damaging floods along the Connecticut River have been recorded since the 1700s. Principal damaging floods of the $20^{\text {th }}$ century occurred in March 1913, November 1927, March 1936, September 1938, and July 1973.

On October 8 and 9, 2005, significant flooding occurred in southwestern New Hampshire as a result of rainfall in excess of 7 in. within a 24-hour period. On Warren Brook, upstream from the village of Alstead, failure of a culvert and a road embankment that was impounding a substantial amount of water also contributed to severe flooding along Warren Brook and downstream on the Cold River in Alstead, Langdon, and Walpole.

Flooding along Warren Brook and the Cold River was the worst ever documented in the area. On November 16, 2005, FEMA authorized the USGS to document the October 2005 flood event and establish new flood-discharge-frequency estimates for the Cold River and Warren Brook (Olson, 2006).

At two discontinued streamgaging stations, Cold River at Drewsville and Ashuelot River at Gilsum, high-water marks exceeded all previously recorded peak stages by several feet. The previously recorded maximum stage and discharge for the period of record at the Cold River station (1940-74) were $12.30 \mathrm{ft}$ and $6,700 \mathrm{ft}^{3} / \mathrm{s}$, respectively. The stage at the Cold River station for the October 2005 flood was $23.7 \mathrm{ft}$, with an estimated discharge of $21,800 \mathrm{ft}^{3} / \mathrm{s}$, which greatly exceeded the 500 -year recurrence-interval discharge $\left(12,700 \mathrm{ft}^{3} / \mathrm{s}\right)$ for the Cold River (Olson, 2006).

\section{Flood-Protection Measures Affecting Warren Brook and Cold River}

There are no major flood control structures along the streams studied. The Connecticut River, however, is regulated by powerplant dams and flood-control reservoirs located on the river and its tributaries. These control measures contribute a combined usable storage capacity of 24.8 billion $\mathrm{ft}^{3}$ (Federal Emergency Management Agency, 2000) for the Connecticut River. A small, unregulated dam is located on Cold Brook at Vilas Pool upstream from the confluence with Warren Brook. Three small, unregulated dams are located on Warren Brookat Warren Lake, at an old mill along State Route 123 in Mill Hollow, and between State Route 123 and Prentice Hill Road. These dams do little to attenuate major flood peaks.

\section{Engineering Methods Used to Determine Flood Data}

For the flooding sources studied in detail in the FIS communities, hydrologic and hydraulic analyses were used to determine the flood data required for this FIS. Flood events that are expected to be equaled or exceeded once on the average during any 10-, 50-, 100-, or 500-year period (recurrence interval) have been selected as having special significance for flood-plain management and for flood insurance rates. These events, commonly termed the 10-, 50-, 100-, and 500-year floods, have a 10-, 2-, 1-, and 0.2-percent chance, respectively, of being equaled or exceeded during any year. Although the recurrence interval represents the long-term average period between floods of a specific magnitude, floods can recur at short intervals and within the same year. The risk of experiencing a flood increases when periods greater than 1 year are considered. For example, the risk of a flood that equals or exceeds the 100-year flood (1-percent chance of annual exceedence) in any 50-year period is approximately 40 percent (4 in 10), and for any 90 -year period, the risk increases to approximately 60 percent (6 in 10). The analyses reported herein reflect flooding potentials based on conditions existing in the community at the time of completion of this study. Maps and flood elevations will need to be amended periodically to reflect future changes.

All FISs and FIRMs are referenced to a specific vertical datum. The vertical datum provides a starting point against which flood, ground, and structure elevations can be referenced and compared. All flood elevations given in this flood recovery study report are referenced to the National Geodetic Vertical Datum of 1929 (NGVD 29), unless otherwise noted. All structure, flood, and ground elevations in the FIS communities are referenced to NGVD 29 in the FIS profiles.

It is important to note that adjacent communities may be referenced to the North American Vertical Datum of 1988 (NAVD 88), which may result in differences in base 
flood elevations across the corporate limits between the communities.

For more information on NAVD 88, see Converting the National Flood Insurance Program to the North American Vertical Datum of 1988, FEMA Publication FIA-20/June 1992, or contact the Vertical Network Branch, National Geodetic Survey, Coast and Geodetic Survey, National Oceanic and Atmospheric Administration, Rockville, Maryland 20910 (Internet address http://www.ngs.noaa.gov).

A description of the reference marks used in this study is presented in Elevation Reference Marks (appendix 3). Elevation reference marks are referenced to NGVD 29.

\section{Hydrologic Analyses}

Hydrologic analyses were used to establish the peak discharge-frequency relations for the Cold River and Warren Brook. For the May 2000 revision of the flood study for Walpole, NH, the USACE performed an analysis of ice jams along the Connecticut River. The analysis of ice-jam flooding required the development of elevation-frequency curves for ice-jam events and free-flow events. The data were plotted using Weibull plotting positions (rank/(n+1)) to develop the ice-jam elevation-frequency curve for two locations along the Connecticut River: a trailer park in Charleston and near the Cheshire Bridge. The elevation-frequency analysis for freeflowing events was taken from the FIS communities' flood profiles for the Connecticut River. The composite elevationfrequency curve (ice-jam and free-flow) was developed by plotting the points on probability paper. For the Cold River in Walpole, the 1980 FIS for Walpole developed flood-flow frequency data by using a log-Pearson Type III analysis of stream frequency-discharge values determined at the USGS streamgaging station on the Cold River (streamgaging station No. 01155000) in Drewsville, NH (Federal Emergency Management Agency, 2000).

For the 2006 revision, peak-flow frequency estimates for Warren Brook were estimated by Olson (2006) by using peak-flow regression equations published in LeBlanc (1978). Basin characteristics used in the regression equations include drainage area, mean channel slope, and the 2-year, 24-hour rainfall for the basin. Drainage area and mean channel slope were determined using a geographic information system (GIS), electronic copies of USGS 1:24,000 topographic maps (U.S. Geological Survey, 1998a-d), and the National Elevation Dataset (U.S. Geological Survey, 2001). The 2-year, 24-hour rainfall was determined from Hershfield (1961). Peak-flow frequency estimates for the Cold River were estimated by Olson (2006) by using a log-Pearson Type III analysis as described in "Guidelines for Determining Flood Flow Frequency" (Interagency Advisory Committee on Water Data, 1982). Data from USGS streamgaging station 01155000 on the Cold River at Drewsville, NH, were used for computing the frequency curve. A "natural" peak for the October 2005 event (without the effect of an embankment breach on Warren Brook) was determined at the Cold River streamgaging station in Drewsville and added to the dataset before analysis (Olson, 2006).

A summary of the drainage area-peak discharge relations for the streams studied by detailed methods in this FIS revision is given in table 1 (Olson, 2006).

Table 1. Summary of the drainage area-peak relations for streams in New Hampshire, studied by detailed methods.

$\left[\mathrm{mi}^{2}\right.$, square mile; $\mathrm{ft}^{3} / \mathrm{s}$, cubic foot per second]

\begin{tabular}{|c|c|c|c|c|c|}
\hline \multirow[t]{2}{*}{ Flooding source and location } & \multirow{2}{*}{$\begin{array}{c}\text { Drainage area } \\
\qquad\left(\mathrm{mi}^{2}\right)\end{array}$} & \multicolumn{4}{|c|}{$\begin{array}{l}\text { Peak discharges } \\
\qquad\left(\mathrm{ft}^{3} / \mathbf{s}\right)\end{array}$} \\
\hline & & 10-year & 50-year & 100-year & 500-year \\
\hline \multicolumn{6}{|c|}{ Cold River } \\
\hline McDermott Bridge, Langdon & 59.2 & 2,930 & 4,910 & 5,980 & 9,090 \\
\hline Vilas Pool Dam, Alstead & 61.3 & 3,030 & 5,080 & 6,190 & 9,410 \\
\hline Route 123 bridge, village of Alstead & 74.6 & 3,690 & 6,190 & 7,530 & 11,500 \\
\hline USGS streamgaging station 01155000, Drewsville & 82.7 & 4,090 & 6,860 & 8,350 & 12,700 \\
\hline Confluence with Connecticut River & 102 & 5,040 & 8,460 & 10,300 & 15,700 \\
\hline \multicolumn{6}{|c|}{ Warren Brook } \\
\hline Mill Hollow & 5.21 & 289 & 508 & 615 & 958 \\
\hline Route 123 temporary bridge & 6.21 & 361 & 640 & 776 & 1,210 \\
\hline Cooper Hill Road & 9.24 & 629 & 1,140 & 1,380 & 2,190 \\
\hline Confluence with Cold River & 12.5 & 805 & 1,430 & 1,740 & 2,710 \\
\hline
\end{tabular}




\section{Hydraulic Analyses}

Analyses of the hydraulic characteristics of flooding from the sources studied were carried out to provide estimates of the elevations of floods at the selected recurrence intervals. Cross sections for the flooding sources studied by detailed methods were obtained from field surveys. Valley and below-water portions of the cross-section data obtained for the Cold River and Warren Brook for this revision were obtained from field measurements. Additional valley portions of cross-section data on Warren Brook were obtained from 2-ft contour data created by Eastern Topographic in the fall of 2005 (Eastern Topographic, 2006) and provided by the NHDOT. All bridges, dams, and culverts were field surveyed to obtain elevation data and structural geometry. Bridge, dam, and culvert crosssection data collection sites were located at close intervals above and below bridges and dams in order to compute the significant backwater effects of these structures. Locations of selected cross sections used in the hydraulic analyses are shown in the flood profiles (appendixes 1 and 2, and in figs. 2-5 (in back of report)).

For this FIS revision, water-surface elevations of floods for the selected recurrence intervals for the Cold River and Warren Brook were computed by using the USACE HEC-RAS (U.S. Army Corps of Engineers, 2005). Starting water-surface elevations for the Cold River were based on normal depth analysis, which is the depth at which flow is steady and hydraulic characteristics are uniform. The model computational procedure is based on the solution of the onedimensional energy equation (U.S. Army Corps of Engineers, 2006). Energy losses are evaluated by friction and contraction and expansion. The momentum equation is used in situations where the water surface is rapidly varied.

Flood profiles were drawn using computed water-surface elevations of floods at the selected recurrence intervals. In those areas where the analysis indicated supercritical flow conditions, critical depth was assumed for the flood elevation because of the inherent instability of supercritical flow.

Manning's " $n$ " roughness factors (Barnes, 1967) used in the hydraulic computations were assigned on the basis of engineering judgment and field observations of the stream and flood-plain areas. Table 2 lists the channel and overbank " $n$ " values for the streams studied by detailed methods.

Table 2. Manning's " $n$ " values for Cold River and Warren Brook.

\begin{tabular}{lll}
\hline \multicolumn{1}{c}{ Stream } & Channel " $\boldsymbol{n}$ " & Overbank " $\boldsymbol{n}$ " \\
\hline Cold River & $0.040-0.070$ & $0.035-0.100$ \\
Warren Brook & $0.045-0.080$ & $0.030-0.110$ \\
\hline
\end{tabular}

The hydraulic analyses for this study were based on an assumption of unobstructed flow. Thus, the flood elevations shown in the profiles are considered valid if hydraulic structures remain unobstructed, operate properly, and do not fail. The resulting flood elevations of the HEC-RAS (U.S. Army Corps of Engineers, 2005) flood analyses for Cold River are shown in table 3, and the results for Warren Brook are shown in table 4.

\section{Flood-Plain Management Applications}

State and local governments are encouraged by the NFIP to adopt sound flood-plain management programs. To provide a national standard without regional discrimination, the 1-percent annual chance (100-year) flood has been adopted by FEMA as the base flood for flood-plain management purposes. The 0.2-percent annual chance (500-year) flood is used to indicate additional areas of flood risk in the FIS communities. Each FIS typically provides 100-year floodplain data, which may include a combination of the following: 10-, 50-, 100-, and 500-year flood elevations; 100- and 500-year flood-plain delineations; and 100-year floodway delineation. In addition to the data presented in the FIS, it is recommended that users reference any additional information that may be available before making flood elevation and/or floodplain boundary determinations. 
Table 3. Cross sections and flood data for Cold River in Alstead, Langdon, and Walpole, New Hampshire.

[Location of cross sections A-AG are in fig. 2, AH-BL are in fig. 3, where scale permits, and in appendix 1; ft, foot; NGVD 29, National Geodetic Vertical Datum of 1929]

\begin{tabular}{|c|c|c|c|c|c|c|}
\hline \multirow{2}{*}{$\begin{array}{l}\text { Cold River } \\
\text { cross section }\end{array}$} & \multirow{2}{*}{$\begin{array}{l}\text { Cumulative } \\
\text { distance } \\
\text { upstream } \\
\text { (ft) }\end{array}$} & \multirow{2}{*}{$\begin{array}{c}\text { Channel } \\
\text { elevation } \\
\text { (ft, NGVD 29) }\end{array}$} & \multicolumn{4}{|c|}{$\begin{array}{l}\text { Annual chance flood elevation } \\
\text { (ft, NGVD 29) }\end{array}$} \\
\hline & & & $\begin{array}{l}10 \text { percent } \\
\text { (10-year) }\end{array}$ & $\begin{array}{l}2 \text { percent } \\
\text { (50-year) }\end{array}$ & $\begin{array}{l}1 \text { percent } \\
\text { (100-year) }\end{array}$ & $\begin{array}{l}0.2 \text { percent } \\
\text { (500-year) }\end{array}$ \\
\hline A & 290.0 & 226.6 & ${ }^{1} 244.6$ & ${ }^{1} 250.2$ & ${ }^{1} 252.8$ & ${ }^{1} 260.0$ \\
\hline B & 408.0 & 219.5 & ${ }^{1} 244.6$ & ${ }^{1} 250.2$ & ${ }^{1} 252.8$ & ${ }^{1} 260.0$ \\
\hline $\mathrm{C}$ & 466.5 & 219.5 & ${ }^{1244.6}$ & ${ }^{1} 250.2$ & ${ }^{1} 252.8$ & ${ }^{1} 260.0$ \\
\hline $\mathrm{D}$ & 751.5 & 226.0 & ${ }^{1} 244.6$ & ${ }^{1} 250.2$ & ${ }^{1} 252.8$ & 1260.0 \\
\hline $\mathrm{E}$ & $1,499.5$ & 230.1 & ${ }^{1} 244.6$ & ${ }^{1} 250.2$ & ${ }^{1} 252.8$ & ${ }^{1} 260.0$ \\
\hline $\mathrm{F}$ & $1,582.5$ & 230.7 & ${ }^{1} 244.6$ & ${ }^{1} 250.2$ & ${ }^{1} 252.8$ & ${ }^{1} 260.0$ \\
\hline G & $1,654.5$ & 230.3 & ${ }^{1} 244.6$ & ${ }^{1} 250.2$ & ${ }^{1} 252.8$ & ${ }^{1} 260.0$ \\
\hline $\mathrm{H}$ & $1,708.5$ & 230.5 & ${ }^{1} 244.6$ & ${ }^{1} 250.2$ & ${ }^{1} 252.8$ & ${ }^{1} 260.0$ \\
\hline I & $1,791.5$ & 231.0 & ${ }^{1} 244.6$ & ${ }^{1} 250.2$ & ${ }^{1} 252.8$ & ${ }^{1} 260.0$ \\
\hline $\mathrm{J}$ & $1,871.5$ & 230.5 & ${ }^{1} 244.6$ & ${ }^{1} 250.2$ & ${ }^{1} 252.8$ & ${ }^{1} 260.0$ \\
\hline K & $2,369.5$ & 234.1 & ${ }^{1} 244.6$ & ${ }^{1} 250.2$ & ${ }^{1} 252.8$ & ${ }^{1} 260.0$ \\
\hline $\mathrm{L}$ & $3,251.5$ & 235.9 & 245.0 & ${ }^{1} 250.2$ & ${ }^{1} 252.8$ & ${ }^{1} 260.0$ \\
\hline M & $5,223.5$ & 247.0 & 253.2 & 255.1 & 255.5 & ${ }^{1} 260.0$ \\
\hline $\mathrm{N}$ & $6,527.5$ & 254.5 & 263.2 & 265.4 & 266.6 & 268.9 \\
\hline $\mathrm{O}$ & $7,287.5$ & 258.7 & 266.4 & 268.7 & 269.7 & 272.1 \\
\hline $\mathrm{P}$ & $9,382.5$ & 279.4 & 285.4 & 287.3 & 288.2 & 290.6 \\
\hline Q & $10,815.5$ & 285.3 & 295.9 & 298.7 & 299.9 & 302.8 \\
\hline $\mathrm{R}$ & $11,955.5$ & 291.2 & 300.4 & 303.5 & 304.8 & 307.8 \\
\hline $\mathrm{S}$ & $13,643.5$ & 302.1 & 310.3 & 312.3 & 312.9 & 314.4 \\
\hline $\mathrm{T}$ & $15,013.5$ & 310.1 & 318.2 & 320.6 & 321.6 & 323.6 \\
\hline $\mathrm{U}$ & $15,968.5$ & 311.9 & 319.9 & 322.2 & 323.2 & 325.5 \\
\hline V & $18,123.5$ & 342.1 & 346.1 & 347.7 & 348.5 & 350.5 \\
\hline W & $18,301.5$ & 353.9 & 362.1 & 365.4 & 367.0 & 371.2 \\
\hline$X$ & $18,349.5$ & 374.2 & 381.3 & 383.4 & 384.4 & 386.9 \\
\hline Y & $18,379.5$ & 374.2 & 383.6 & 387.2 & 388.9 & 394.4 \\
\hline $\mathrm{Z}$ & $18,520.5$ & 377.7 & 384.8 & 388.6 & 390.4 & 395.2 \\
\hline AA & $18,565.5$ & 379.9 & 385.1 & 388.8 & 390.6 & 395.4 \\
\hline $\mathrm{AB}$ & $19,453.5$ & 383.6 & 390.4 & 391.1 & 392.0 & 395.8 \\
\hline $\mathrm{AC}$ & $21,358.5$ & 392.8 & 398.5 & 399.9 & 400.4 & 401.6 \\
\hline $\mathrm{AD}$ & $21,893.5$ & 394.3 & 402.1 & 403.5 & 404.0 & 405.1 \\
\hline $\mathrm{AE}$ & $22,482.5$ & 397.7 & 404.7 & 406.0 & 406.5 & 407.7 \\
\hline $\mathrm{AF}$ & $23,118.5$ & 400.9 & 408.6 & 409.4 & 409.7 & 410.5 \\
\hline $\mathrm{AG}$ & $23,923.5$ & 404.6 & 411.7 & 412.9 & 413.4 & 414.5 \\
\hline $\mathrm{AH}$ & $25,713.5$ & 417.0 & 423.0 & 423.9 & 424.3 & 425.3 \\
\hline $\mathrm{AI}$ & $26,444.5$ & 426.6 & 431.0 & 431.9 & 432.3 & 433.2 \\
\hline
\end{tabular}


Table 3. Cross sections and flood data for Cold River in Alstead, Langdon, and Walpole, New Hampshire.-Continued [Location of cross sections A-AG are in fig. 2, AH-BL are in fig. 3, where scale permits, and in appendix 1; ft, foot; NGVD 29, National Geodetic Vertical Datum of 1929]

\begin{tabular}{|c|c|c|c|c|c|c|}
\hline \multirow{2}{*}{$\begin{array}{l}\text { Cold River } \\
\text { cross section }\end{array}$} & \multirow{2}{*}{$\begin{array}{l}\text { Cumulative } \\
\text { distance } \\
\text { upstream } \\
\text { (ft) }\end{array}$} & \multirow{2}{*}{$\begin{array}{c}\text { Channel } \\
\text { elevation } \\
\text { (ft, NGVD 29) }\end{array}$} & \multicolumn{4}{|c|}{$\begin{array}{c}\text { Annual chance flood elevation } \\
\text { (ft, NGVD 29) }\end{array}$} \\
\hline & & & $\begin{array}{c}10 \text { percent } \\
\text { (10-year) }\end{array}$ & $\begin{array}{l}2 \text { percent } \\
\text { (50-year) }\end{array}$ & $\begin{array}{l}1 \text { percent } \\
\text { (100-year) }\end{array}$ & $\begin{array}{l}0.2 \text { percent } \\
\text { (500-year) }\end{array}$ \\
\hline $\mathrm{AJ}$ & $27,831.5$ & 433.6 & 441.2 & 442.4 & 442.9 & 444.1 \\
\hline $\mathrm{AK}$ & $28,921.5$ & 442.9 & 448.9 & 450.3 & 450.7 & 452.3 \\
\hline $\mathrm{AL}$ & $30,419.5$ & 452.6 & 461.3 & 463.7 & 464.8 & 467.0 \\
\hline $\mathrm{AM}$ & $30,591.5$ & 450.5 & 461.9 & 464.3 & 465.3 & 467.3 \\
\hline AN & $30,642.0$ & 450.2 & 462.1 & 464.6 & 465.7 & 468.0 \\
\hline $\mathrm{AO}$ & $30,850.0$ & 454.7 & 464.8 & 467.6 & 468.9 & 472.2 \\
\hline $\mathrm{AP}$ & $31,588.0$ & 468.1 & 473.2 & 474.6 & 475.4 & 477.6 \\
\hline $\mathrm{AQ}$ & $32,609.0$ & 478.5 & 486.3 & 487.7 & 488.3 & 489.8 \\
\hline $\mathrm{AR}$ & $33,510.0$ & 490.4 & 500.1 & 502.6 & 504.0 & 506.6 \\
\hline AS & $33,714.0$ & 499.4 & 506.5 & 509.3 & 510.3 & 513.2 \\
\hline $\mathrm{AT}$ & $33,965.0$ & 497.8 & 508.7 & 511.0 & 512.1 & 514.8 \\
\hline $\mathrm{AU}$ & $34,084.0$ & 503.2 & 510.3 & 512.5 & 513.6 & 516.5 \\
\hline $\mathrm{AV}$ & $34,290.0$ & 508.9 & 514.2 & 515.7 & 516.6 & 518.5 \\
\hline AW & $34,925.0$ & 513.0 & 519.5 & 520.8 & 521.1 & 523.3 \\
\hline $\mathrm{AX}$ & $35,070.0$ & 515.5 & 521.9 & 524.2 & 525.6 & 528.4 \\
\hline $\mathrm{AY}$ & $35,125.0$ & 523.5 & 539.9 & 542.4 & 543.6 & 545.9 \\
\hline $\mathrm{AZ}$ & $35,195.0$ & 523.5 & 539.9 & 542.4 & 543.6 & 545.9 \\
\hline BA & $36,205.0$ & 537.0 & 539.7 & 542.6 & 543.8 & 546.2 \\
\hline $\mathrm{BB}$ & $36,305.0$ & 537.0 & 541.7 & 542.4 & 543.6 & 546.1 \\
\hline $\mathrm{BC}$ & $38,045.0$ & 549.0 & 556.3 & 558.3 & 558.4 & 558.7 \\
\hline $\mathrm{BD}$ & $40,530.0$ & 572.9 & 577.6 & 578.8 & 580.3 & 582.3 \\
\hline $\mathrm{BE}$ & $42,238.0$ & 589.2 & 595.1 & 596.3 & 596.5 & 596.8 \\
\hline $\mathrm{BF}$ & $42,373.0$ & 588.5 & 595.8 & 596.8 & 597.1 & 597.7 \\
\hline BG & $42,407.0$ & 589.8 & 595.9 & 597.0 & 599.4 & 602.2 \\
\hline $\mathrm{BH}$ & $42,420.0$ & 589.8 & 595.9 & 597.0 & 599.1 & 602.1 \\
\hline BI & $42,445.0$ & 589.8 & 596.1 & 597.5 & 599.4 & 602.3 \\
\hline BJ & $42,455.0$ & 589.8 & 596.2 & 597.6 & 599.5 & 602.3 \\
\hline BK & $42,465.0$ & 589.8 & 596.3 & 597.7 & 599.6 & 602.3 \\
\hline BL & $42,530.0$ & 590.3 & 596.6 & 598.8 & 600.5 & 602.8 \\
\hline
\end{tabular}

${ }^{1}$ Backwater elevation from the Connecticut River. 
Table 4. Cross sections and flood data for Warren Brook in Alstead, New Hampshire.

[Location of cross sections A-AA are in fig. 4, AB-BD are in fig. 5, where scale permits, and in appendix 2; ft, foot; NGVD 29, National Geodetic Vertical Datum of 1929]

\begin{tabular}{|c|c|c|c|c|c|c|}
\hline \multirow{2}{*}{$\begin{array}{l}\text { Warren Brook } \\
\text { cross section }\end{array}$} & \multirow{2}{*}{$\begin{array}{c}\text { Cumulative } \\
\text { distance } \\
\text { upstream } \\
\text { (ft) }\end{array}$} & \multirow{2}{*}{$\begin{array}{c}\text { Channel } \\
\text { elevation } \\
\text { (ft, NGVD 29) }\end{array}$} & \multicolumn{4}{|c|}{$\begin{array}{l}\text { Annual chance flood elevation } \\
\text { (ft, NGVD 29) }\end{array}$} \\
\hline & & & $\begin{array}{l}10 \text { percent } \\
\text { (10-year) }\end{array}$ & $\begin{array}{l}2 \text { percent } \\
\text { (50-year) }\end{array}$ & $\begin{array}{l}1 \text { percent } \\
\text { (100-year) }\end{array}$ & $\begin{array}{r}0.2 \text { percent } \\
\text { (500-year) }\end{array}$ \\
\hline A & 0.0 & 500.1 & 509.9 & 512.4 & 513.6 & 516.6 \\
\hline B & 89.0 & 504.2 & 509.6 & 512.3 & 513.5 & 516.6 \\
\hline $\mathrm{C}$ & 96.0 & 504.3 & 510.3 & 512.9 & 514.0 & 516.6 \\
\hline D & 185.5 & 507.3 & 511.1 & 513.2 & 514.2 & 516.3 \\
\hline E & 222.5 & 508.2 & 512.8 & 514.6 & 515.4 & 518.1 \\
\hline F & 248.5 & 508.2 & 513.4 & 515.3 & 516.3 & 519.9 \\
\hline G & 301.5 & 511.3 & 515.4 & 517.6 & 517.9 & 520.0 \\
\hline $\mathrm{H}$ & 846.5 & 521.2 & 525.4 & 526.3 & 526.7 & 527.0 \\
\hline I & $2,366.5$ & 582.9 & 586.4 & 587.2 & 587.6 & 588.6 \\
\hline $\mathrm{J}$ & $2,516.5$ & 588.2 & 592.9 & 594.1 & 594.7 & 596.1 \\
\hline K & $2,664.5$ & 587.2 & 595.6 & 597.5 & 598.2 & 599.9 \\
\hline $\mathrm{L}$ & $3,261.5$ & 604.7 & 608.8 & 610.6 & 611.1 & 611.9 \\
\hline M & $4,160.5$ & 629.5 & 633.6 & 635.1 & 635.8 & 637.3 \\
\hline $\mathrm{N}$ & $4,578.5$ & 639.7 & 642.9 & 644.0 & 644.5 & 645.8 \\
\hline $\mathrm{O}$ & $4,862.5$ & 646.3 & 649.9 & 650.7 & 651.1 & 651.9 \\
\hline $\mathrm{P}$ & $4,948.5$ & 649.3 & 652.0 & 653.3 & 653.8 & 656.8 \\
\hline Q & $4,974.5$ & 647.8 & 653.3 & 654.9 & 656.0 & 658.6 \\
\hline $\mathrm{R}$ & $5,061.5$ & 650.5 & 654.4 & 656.0 & 656.9 & 658.7 \\
\hline S & $5,851.5$ & 663.8 & 665.9 & 666.3 & 666.5 & 667.1 \\
\hline $\mathrm{T}$ & $5,903.5$ & 663.7 & 667.2 & 668.5 & 669.1 & 671.0 \\
\hline $\mathrm{U}$ & $5,962.5$ & 663.8 & 670.3 & 673.0 & 673.4 & 673.8 \\
\hline $\mathrm{V}$ & $5,994.5$ & 665.0 & 671.7 & 673.2 & 673.5 & 674.0 \\
\hline W & $7,076.5$ & 689.2 & 691.6 & 692.2 & 692.4 & 693.0 \\
\hline $\mathrm{X}$ & $8,082.5$ & 708.3 & 712.4 & 713.6 & 714.0 & 715.1 \\
\hline $\mathrm{Y}$ & $8,769.5$ & 718.8 & 721.4 & 722.6 & 723.1 & 724.5 \\
\hline $\mathrm{Z}$ & $10,221.5$ & 750.9 & 754.5 & 755.3 & 755.8 & 756.9 \\
\hline AA & $11,036.5$ & 775.9 & 779.5 & 780.9 & 781.4 & 783.4 \\
\hline $\mathrm{AB}$ & $12,058.5$ & 798.0 & 800.7 & 801.8 & 802.2 & 803.2 \\
\hline $\mathrm{AC}$ & $12,208.5$ & 795.5 & 801.7 & 803.0 & 803.5 & 804.9 \\
\hline $\mathrm{AD}$ & $12,221.5$ & 796.4 & 801.4 & 802.6 & 803.0 & 804.1 \\
\hline $\mathrm{AE}$ & $12,283.5$ & 797.4 & 802.1 & 803.6 & 804.2 & 805.8 \\
\hline $\mathrm{AF}$ & $12,386.5$ & 799.8 & 803.3 & 804.8 & 805.3 & 807.0 \\
\hline $\mathrm{AG}$ & $13,156.5$ & 804.8 & 807.9 & 809.0 & 809.5 & 810.9 \\
\hline $\mathrm{AH}$ & $15,160.5$ & 823.3 & 826.0 & 826.4 & 826.5 & 826.9 \\
\hline AI & $16,741.5$ & 845.6 & 850.1 & 851.6 & 852.1 & 853.8 \\
\hline
\end{tabular}


Table 4. Cross sections and flood data for Warren Brook in Alstead, New Hampshire._-Continued

[Location of cross sections A-AA are in fig. 4, AB-BD are in fig. 5, where scale permits, and in appendix 2; ft, foot; NGVD 29, National Geodetic Vertical Datum of 1929]

\begin{tabular}{|c|c|c|c|c|c|c|}
\hline \multirow{2}{*}{$\begin{array}{l}\text { Warren Brook } \\
\text { cross section }\end{array}$} & \multirow{2}{*}{$\begin{array}{l}\text { Cumulative } \\
\text { distance } \\
\text { upstream } \\
\text { (ft) }\end{array}$} & \multirow{2}{*}{$\begin{array}{c}\text { Channel } \\
\text { elevation } \\
\text { (ft, NGVD 29) }\end{array}$} & \multicolumn{4}{|c|}{$\begin{array}{l}\text { Annual chance flood elevation } \\
\text { (ft, NGVD 29) }\end{array}$} \\
\hline & & & $\begin{array}{l}10 \text { percent } \\
\text { (10-year) }\end{array}$ & $\begin{array}{l}2 \text { percent } \\
\text { (50-year) }\end{array}$ & $\begin{array}{l}1 \text { percent } \\
\text { (100-year) }\end{array}$ & $\begin{array}{l}0.2 \text { percent } \\
\text { (500-year) }\end{array}$ \\
\hline $\mathrm{AJ}$ & $16,810.5$ & 846.0 & 850.5 & 852.1 & 852.9 & 854.7 \\
\hline AK & $16,902.5$ & 845.8 & 853.1 & 853.9 & 854.2 & 854.9 \\
\hline $\mathrm{AL}$ & $16,955.5$ & 845.9 & 853.3 & 854.1 & 854.4 & 855.2 \\
\hline $\mathrm{AM}$ & $18,324.5$ & 900.5 & 902.3 & 903.0 & 903.3 & 904.1 \\
\hline AN & $18,414.5$ & 902.1 & 905.1 & 905.9 & 906.3 & 907.1 \\
\hline $\mathrm{AO}$ & $18,456.5$ & 902.7 & 905.5 & 906.3 & 906.7 & 907.4 \\
\hline AP & $18,502.5$ & 905.6 & 910.3 & 911.5 & 911.9 & 912.9 \\
\hline AQ & $18,976.5$ & 924.9 & 927.3 & 928.3 & 928.7 & 929.8 \\
\hline AR & $19,342.5$ & 950.4 & 952.3 & 953.1 & 953.4 & 954.4 \\
\hline AS & $20,176.5$ & $1,010.5$ & $1,012.7$ & $1,013.5$ & $1,013.9$ & $1,014.8$ \\
\hline $\mathrm{AT}$ & $21,346.5$ & $1,067.0$ & $1,069.7$ & $1,070.2$ & $1,070.4$ & $1,070.9$ \\
\hline $\mathrm{AU}$ & $21,418.5$ & $1,071.4$ & $1,074.5$ & $1,075.5$ & $1,075.9$ & $1,077.1$ \\
\hline $\mathrm{AV}$ & $21,555.5$ & $1,081.9$ & $1,090.2$ & $1,097.9$ & $1,103.3$ & $1,103.4$ \\
\hline AW & $21,570.5$ & $1,084.7$ & $1,090.3$ & $1,098.0$ & $1,103.4$ & $1,103.6$ \\
\hline AX & $22,872.5$ & $1,164.1$ & $1,166.5$ & $1,167.4$ & $1,167.8$ & $1,168.9$ \\
\hline AY & $22,935.5$ & $1,171.0$ & $1,172.8$ & $1,173.4$ & 1173.7 & $1,174.4$ \\
\hline $\mathrm{AZ}$ & $22,975.5$ & $1,170.5$ & $1,174.3$ & $1,175.1$ & $1,175.5$ & $1,176.4$ \\
\hline $\mathrm{BA}$ & $23,059.5$ & $1,175.3$ & $1,176.9$ & $1,177.6$ & $1,177.9$ & $1,178.8$ \\
\hline $\mathrm{BB}$ & $23,065.5$ & $1,180.8$ & $1,191.5$ & $1,192.8$ & $1,193.3$ & $1,193.9$ \\
\hline $\mathrm{BC}$ & $23,091.5$ & $1,180.8$ & $1,191.5$ & $1,192.8$ & $1,193.3$ & $1,194.0$ \\
\hline $\mathrm{BD}$ & $23,136.5$ & $1,185.2$ & $1,192.8$ & $1,195.4$ & $1,195.7$ & $1,196.3$ \\
\hline $\mathrm{BE}$ & $23,186.5$ & $1,185.6$ & $1,193.0$ & $1,195.4$ & $1,195.7$ & $1,196.3$ \\
\hline $\mathrm{BF}$ & $23,244.5$ & $1,186.6$ & $1,193.0$ & $1,195.4$ & $1,195.7$ & $1,196.4$ \\
\hline BG & $23,364.5$ & $1,188.5$ & $1,193.0$ & $1,195.4$ & $1,195.7$ & $1,196.4$ \\
\hline $\mathrm{BH}$ & $23,494.5$ & $1,190.9$ & $1,192.9$ & $1,195.4$ & $1,195.7$ & $1,196.4$ \\
\hline $\mathrm{BI}$ & $23,612.5$ & $1,190.3$ & $1,197.1$ & $1,197.9$ & $1,199.0$ & $1,199.6$ \\
\hline $\mathrm{BJ}$ & $23,632.5$ & $1,190.3$ & $1,198.1$ & $1,199.0$ & $1,199.5$ & $1,200.1$ \\
\hline $\mathrm{BK}$ & $23,667.5$ & $1,192.3$ & $1,198.8$ & 1,199.6 & $1,199.9$ & $1,200.5$ \\
\hline $\mathrm{BL}$ & $23,698.5$ & $1,192.1$ & $1,198.8$ & $1,199.6$ & $1,200.0$ & $1,200.5$ \\
\hline $\mathrm{BM}$ & $23,732.5$ & $1,192.7$ & $1,199.7$ & $1,200.6$ & $1,200.8$ & $1,201.2$ \\
\hline $\mathrm{BN}$ & $23,776.5$ & 1,193.6 & $1,199.8$ & $1,200.6$ & $1,200.9$ & $1,201.3$ \\
\hline $\mathrm{BO}$ & $23,791.5$ & $1,193.6$ & $1,201.9$ & $1,202.8$ & $1,203.1$ & $1,203.5$ \\
\hline
\end{tabular}




\section{Summary}

Rainfall in excess of 7 inches resulted in severe flooding on October 8 and 9, 2005, along Warren Brook in Alstead, $\mathrm{NH}$, and Cold River in Walpole, Alstead, and Langdon, NH. This flood recovery study was undertaken to help guide redevelopment and the replacement of damaged infrastructure, allocate appropriate State and Federal recovery resources, and ensure that effective mitigation measures are in place to avoid future flood losses.

Water surface elevations and profiles as determined using the U.S. Army Corps of Engineers (USACE) one-dimensional Hydrologic Engineering Center River Analysis System, also known as HEC-RAS (U.S. Army Corps of Engineers, 2005) are presented in this report. Flood events of a magnitude that are expected to be equaled or exceeded once on the average during any 10-, 50-, 100-, or 500-year period (recurrence interval) were modeled using HEC-RAS as these flood events have been selected as being significant for flood-plain management, determination of flood insurance rates, and design of structures such as bridges and culverts. The analyses in this study reflect the flooding potentials based on conditions existing in the communities of Walpole, Alstead, and Langdon at the time of completion of this study.

\section{References Cited}

Barnes, H.H., Jr., 1967, Roughness characteristics of natural channels: U.S. Geological Survey Water-Supply Paper $1849,213 \mathrm{p}$.

Cold River Local Advisory Committee, 2006, A detailed geological history of the Cold River, accessed on October 23, 2006, at http://www.coldriver.org/geology.htm.

Eastern Topographic, 2006, Alstead preliminary plan view with two-foot contours of combined SDR and aerial survey, January 12, 2006, scale 1:1,2000.

Federal Emergency Management Agency, 1975, Flood hazard boundary map, town of Langdon, Sullivan County, New Hampshire: Washington, D.C., January 3, 1975.

Federal Emergency Management Agency, 1986, Flood Insurance Rate Map, town of Alstead, Cheshire County, New Hampshire: Washington, D.C., April 2, 1986.

Federal Emergency Management Agency, 2000, Flood Insurance Rate Map and Flood Insurance Study, town of Walpole, Cheshire County, New Hampshire: Washington, D.C., May 4, 2000.

Hershfield, D.M., 1961, Rainfall frequency atlas of the United States for durations from 30 minutes to 24 hours and return periods from 1 to 100 years: U.S. Department of Commerce Weather Bureau Technical Paper No. 40, 61 p.
Interagency Advisory Committee on Water Data, 1982, Guidelines for determining flood flow frequency, Bulletin 17-B of the hydrology subcommittee: Reston, VA, U.S. Geological Survey, Office of Water Data Coordination, $183 \mathrm{p}$.

LeBlanc, D.R., 1978, Progress report on hydrologic investigations of small drainage areas in New Hampshire-preliminary relations for estimating peak discharges on rural, unregulated streams: U.S. Geological Survey WaterResources Investigations Report 78-47, 10 p.

National Weather Service, 2005, Daily climate data, accessed May 4, 2006, at http://www.erh.noaa.gov/er/box/ dailystns.shtml.

New Hampshire Employment Security, Economic and Labor Market Information Bureau, 2005a, Community profiles (Alstead), accessed March 27, 2006, at http://www.nhes. state.nh.us/elmi/htmlprofiles/alstead.html.

New Hampshire Employment Security, Economic and Labor Market Information Bureau, 2005b, Community profiles (Langdon), accessed March 27, 2006, at http://www.nhes. state.nh.us/elmi/htmlprofiles/langdon.html.

New Hampshire Employment Security, Economic and Labor Market Information Bureau, 2005c, Community profiles (Walpole), accessed March 27, 2006, at http://www.nhes. state.nh.us/elmi/htmlprofiles/walpole.html.

Olson, S.A., 2006, Flood of October 8-10, 2005, on Warren Brook in Alstead and the Cold River in Alstead, Langdon and Walpole, New Hampshire: U.S. Geological Survey Open-File Report 2006-1221.

U.S. Army Corps of Engineers, 2005, Hydrologic Engineering Center-River Analysis System (HEC-RAS), Davis, CA, v. 3.1.3, May 2005.

U.S. Army Corps of Engineers, 2006, Hydrologic Engineering Center-River Analysis System (HEC-RAS), HEC-RAS Philosophy, accessed March 29, 2006, at http://www.hec. usace.army.mil/software/hec-ras/.

U.S. Geological Survey, 1998a, Alstead, New Hampshire 7.5-minute series quadrangle map: U.S. Geological Survey Topographic Map, scale 1:24,000.

U.S. Geological Survey, 1998b, Bellows Falls, VermontNew Hampshire 7.5 minute series quadrangle map: U.S. Geological Survey Topographic Map, scale 1:24,000.

U.S. Geological Survey, 1998c, Gilsum, New Hampshire 7.5-minute series quadrangle map: U.S. Geological Survey Topographic Map, scale 1:24,000.

U.S. Geological Survey, 1998d, Walpole, New HampshireVermont 7.5-minute series quadrangle map: U.S. Geological Survey Topographic Map, scale 1:24,000.

U.S. Geological Survey, 2001, National Elevation Dataset, accessed February 16, 2006, at http://edcnts12.cr.usgs. gov/ned, 


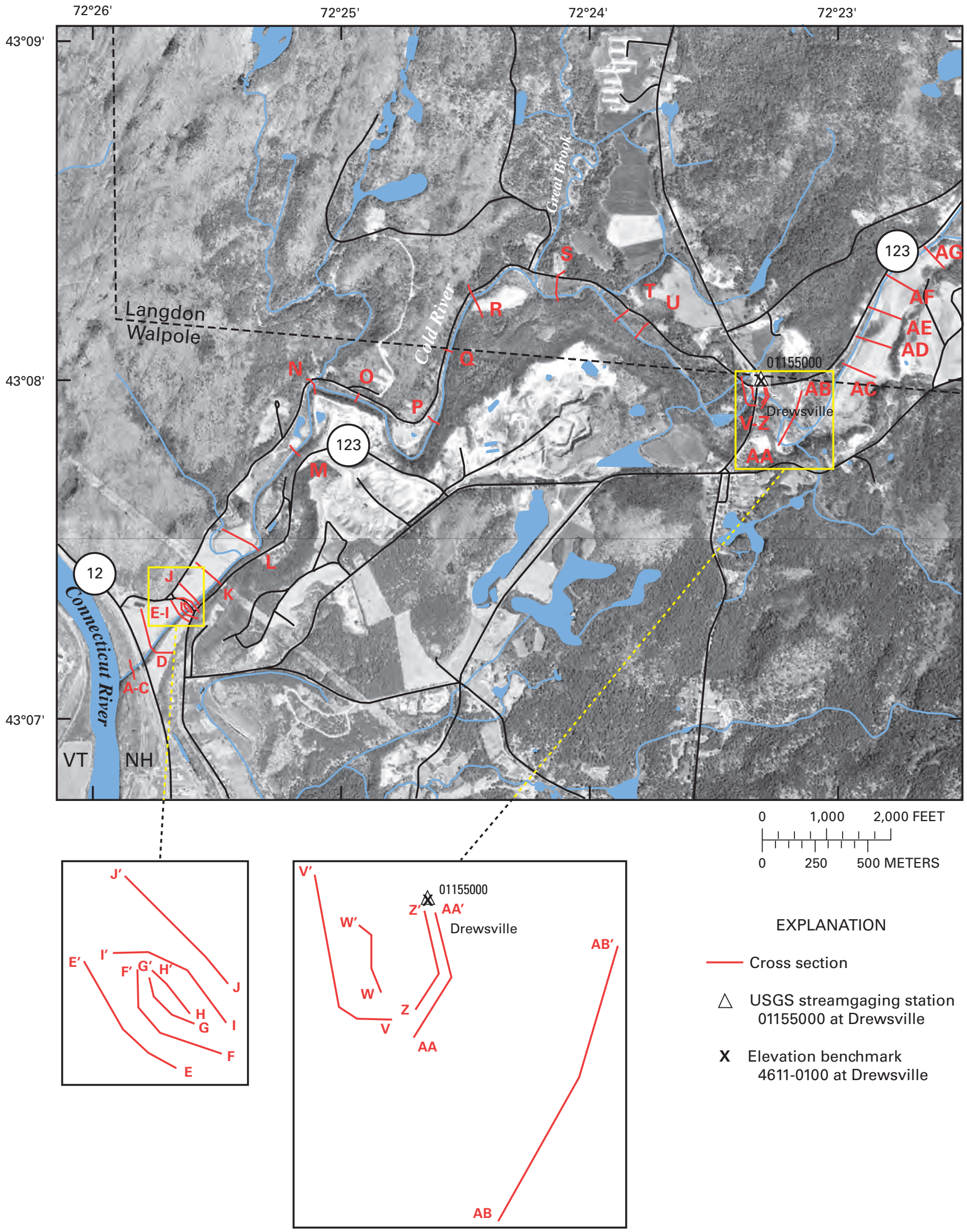

Figure 2. Location of cross sections along Cold River in Walpole and Langdon, New Hampshire. Cross section locations, in relation to streambed and flood profiles, are shown in appendix 1. Cross sections $X$ and $Y$ are not shown on figure 2, but are shown in appendix 1-6. Approximate location of figure 2 is shown in figure 1. 


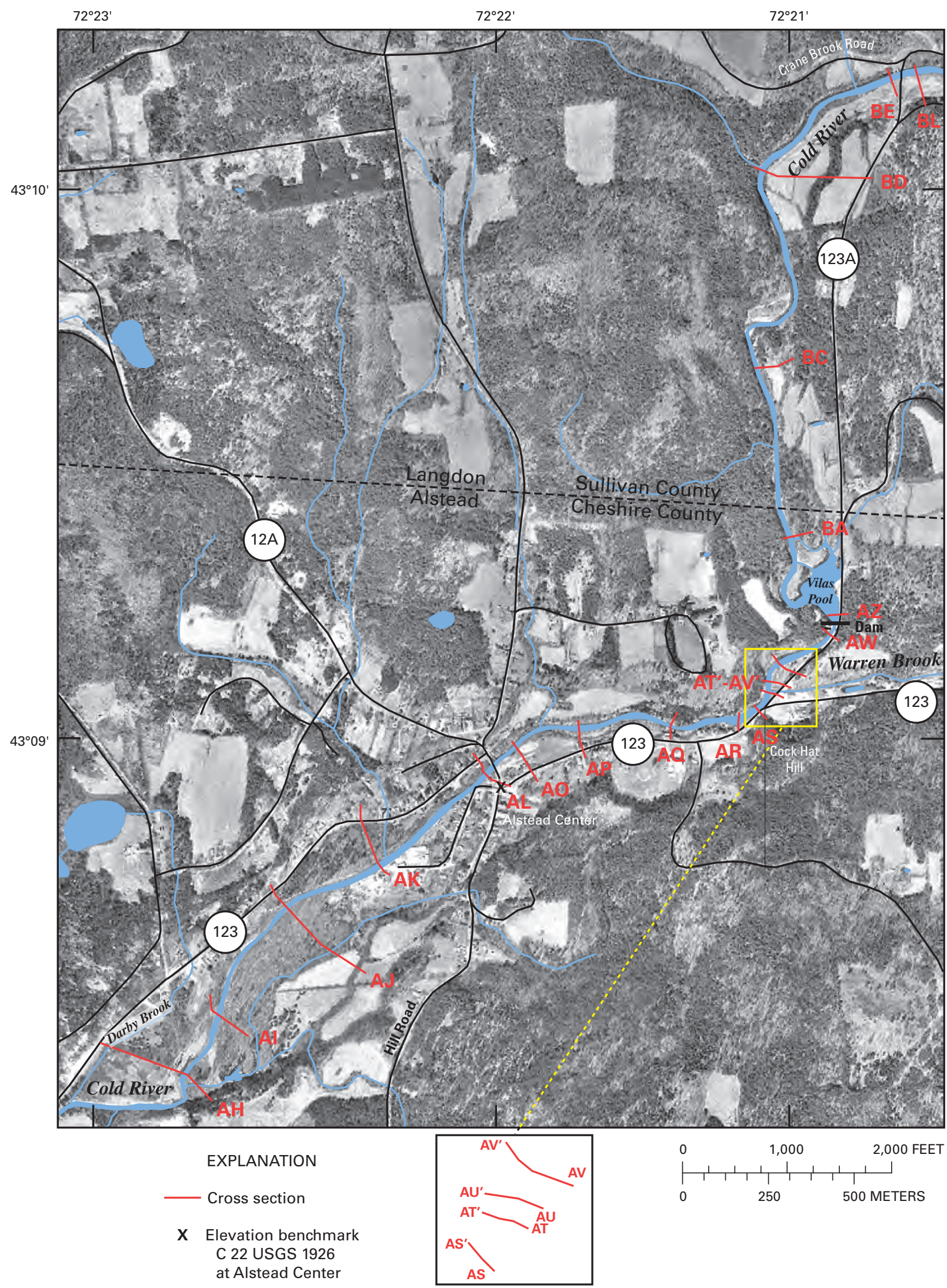

Figure 3. Location of cross sections along Cold River in Alstead and Langdon, New Hampshire. Cross section locations, in relation to streambed and flood profiles, are shown in appendix 1. Cross sections $A M, A N, A X, A Y$, and $B B, B F$, and $B K$, are not shown on figure 3 , but are shown in appendixes 1-6, 1-7, and 1-9. Approximate location of figure 3 is shown in figure 1. 


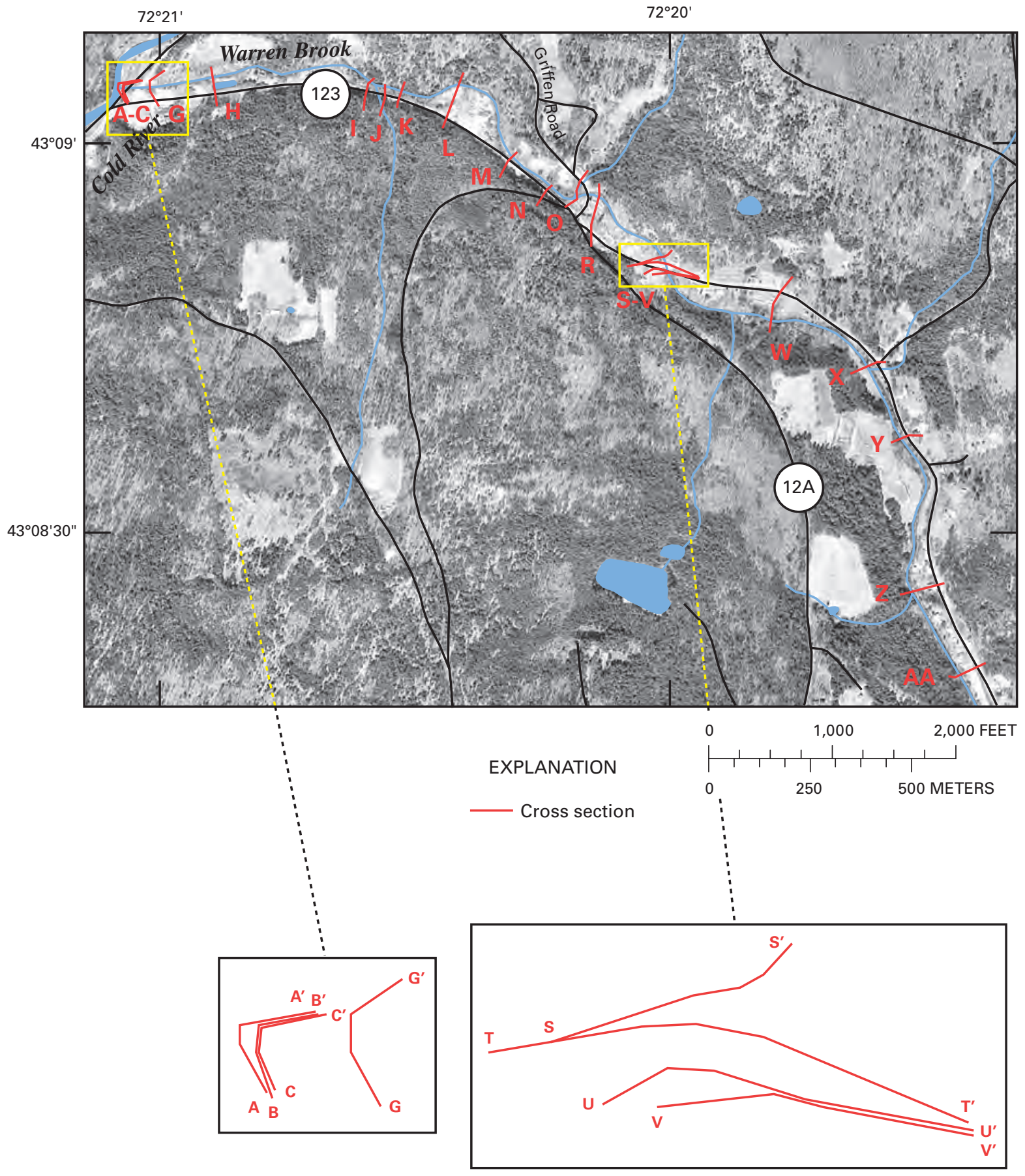

Figure 4. Location of cross sections along Warren Brook in Alstead, New Hampshire. Cross section locations, in relation to streambed and flood profiles, are shown in appendix 2. Cross sections $D, E, F$, and $P$ and $Q$ are not shown on figure 4, but are shown in appendixes 2-1 and 1-4. Approximate location of figure 4 is shown in figure 1. 


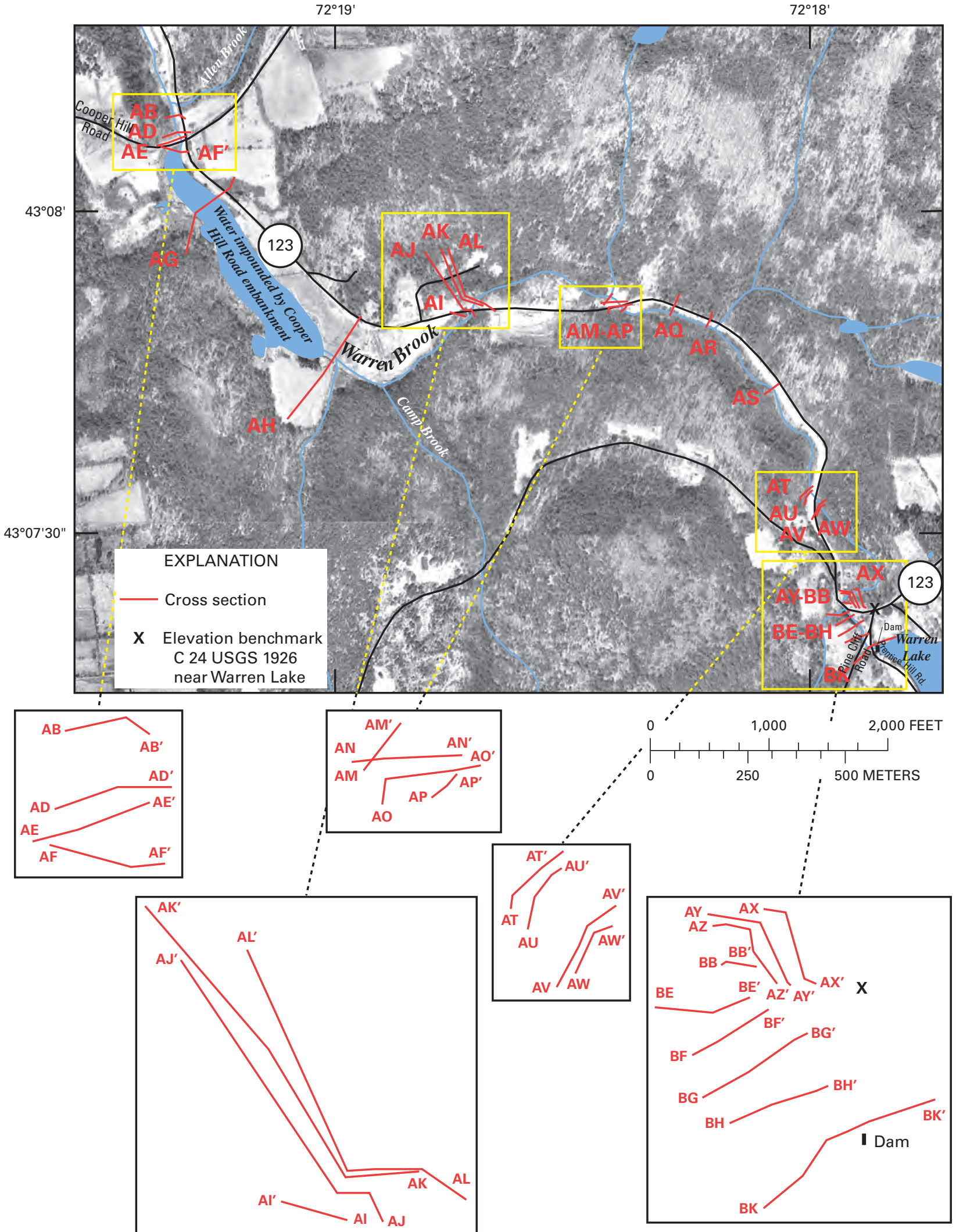

Figure 5. Location of cross sections along Warren Brook in Alstead, New Hampshire. Cross section locations, in relation to streambed and flood profiles, are shown in appendix 2. Cross sections AC, BA, BC, BD, BI, BJ, BL, BM, BN, and B0 are not shown in figure 5, but in appendixes 2-11, 2-18, and 2-19. Approximate location of figure 5 is shown in figure 1. 



\section{Appendix 1: Cold River Flood Profiles}




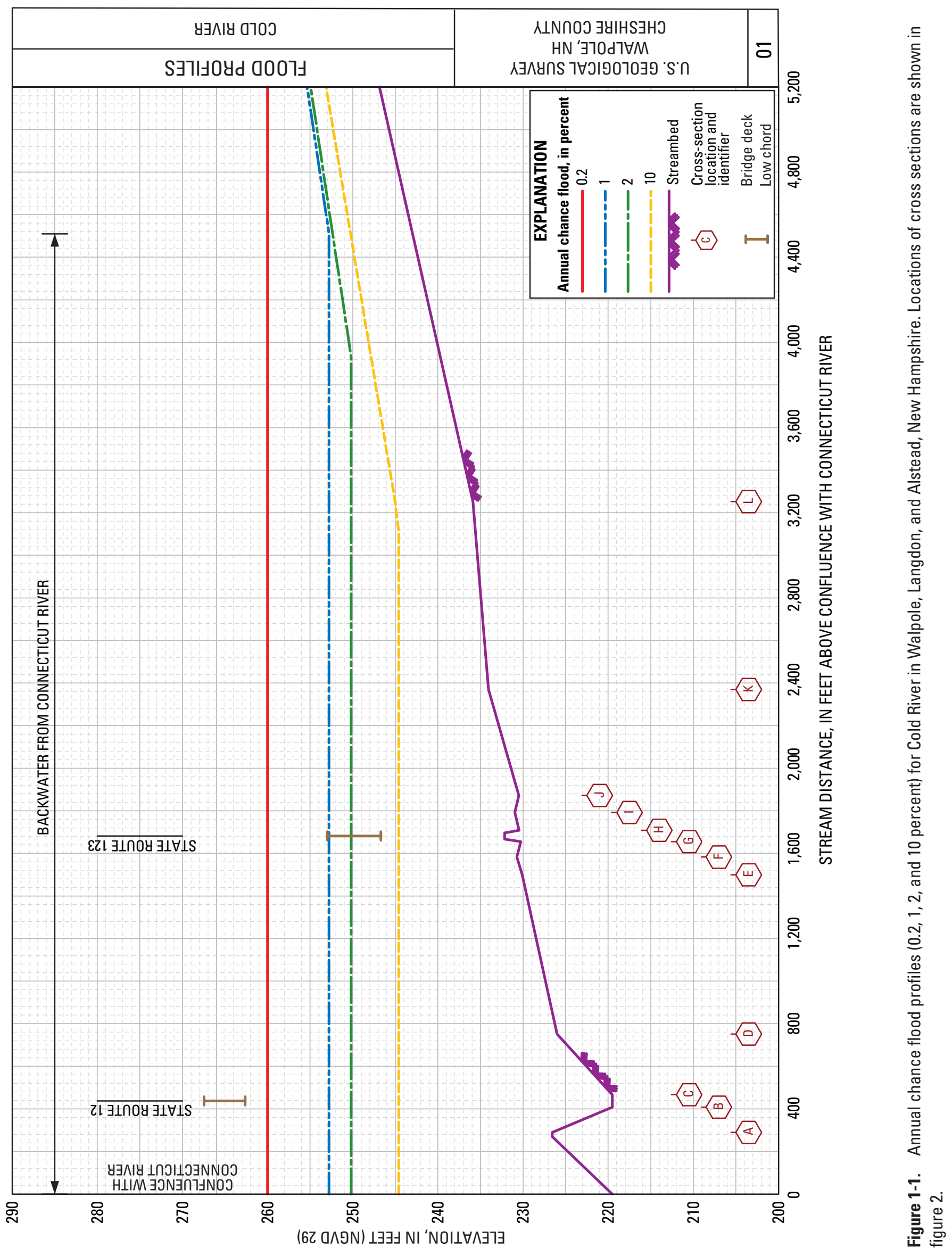




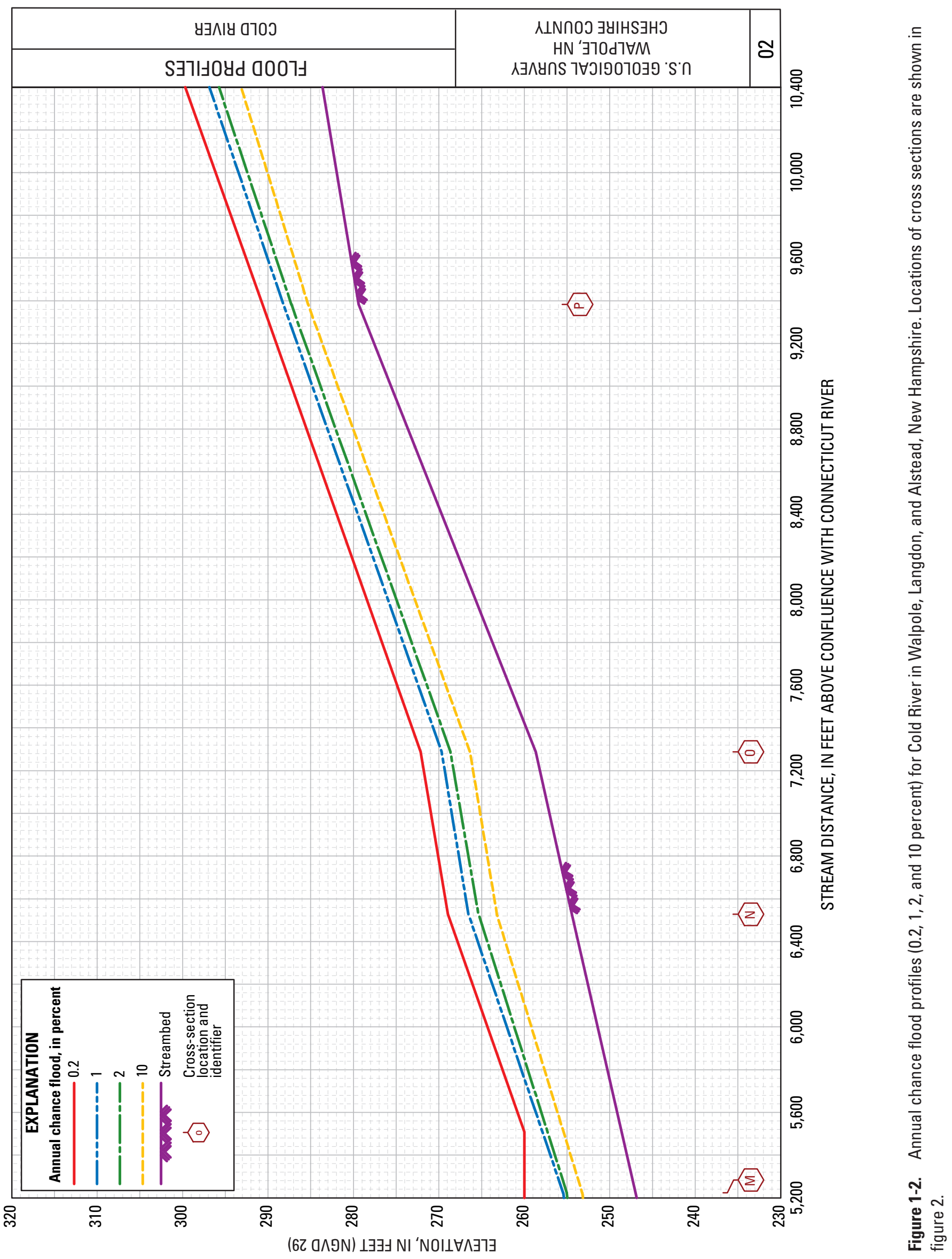




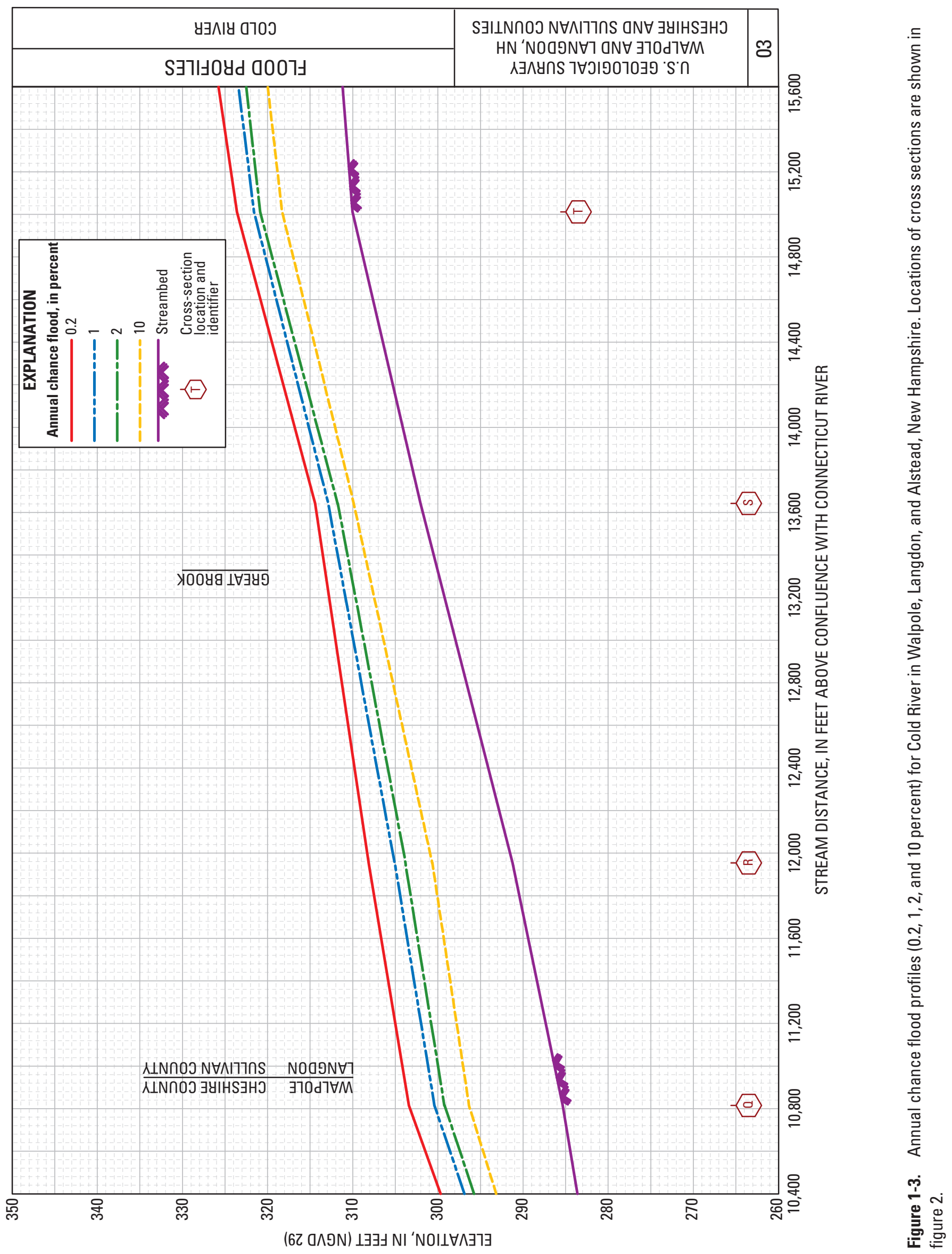




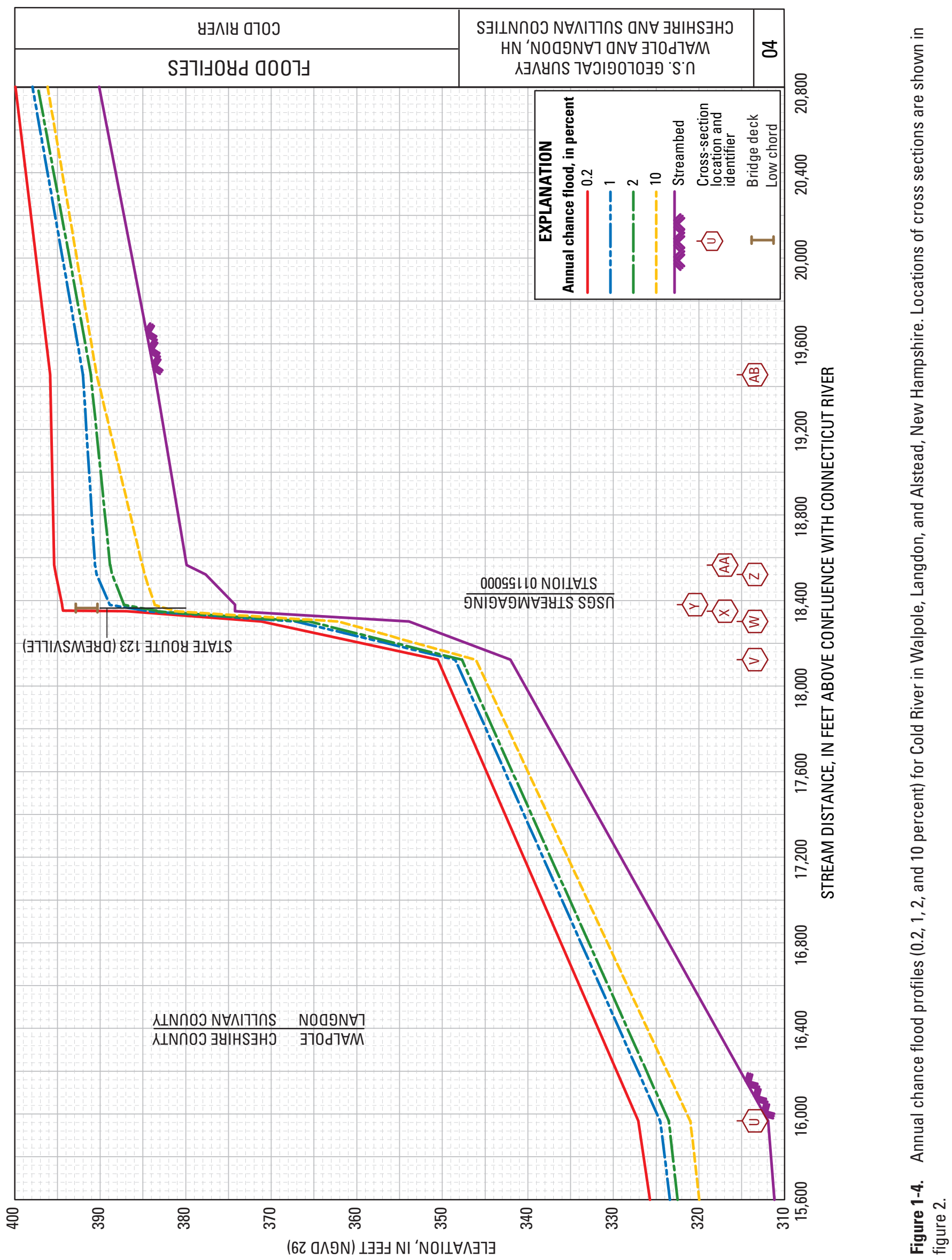




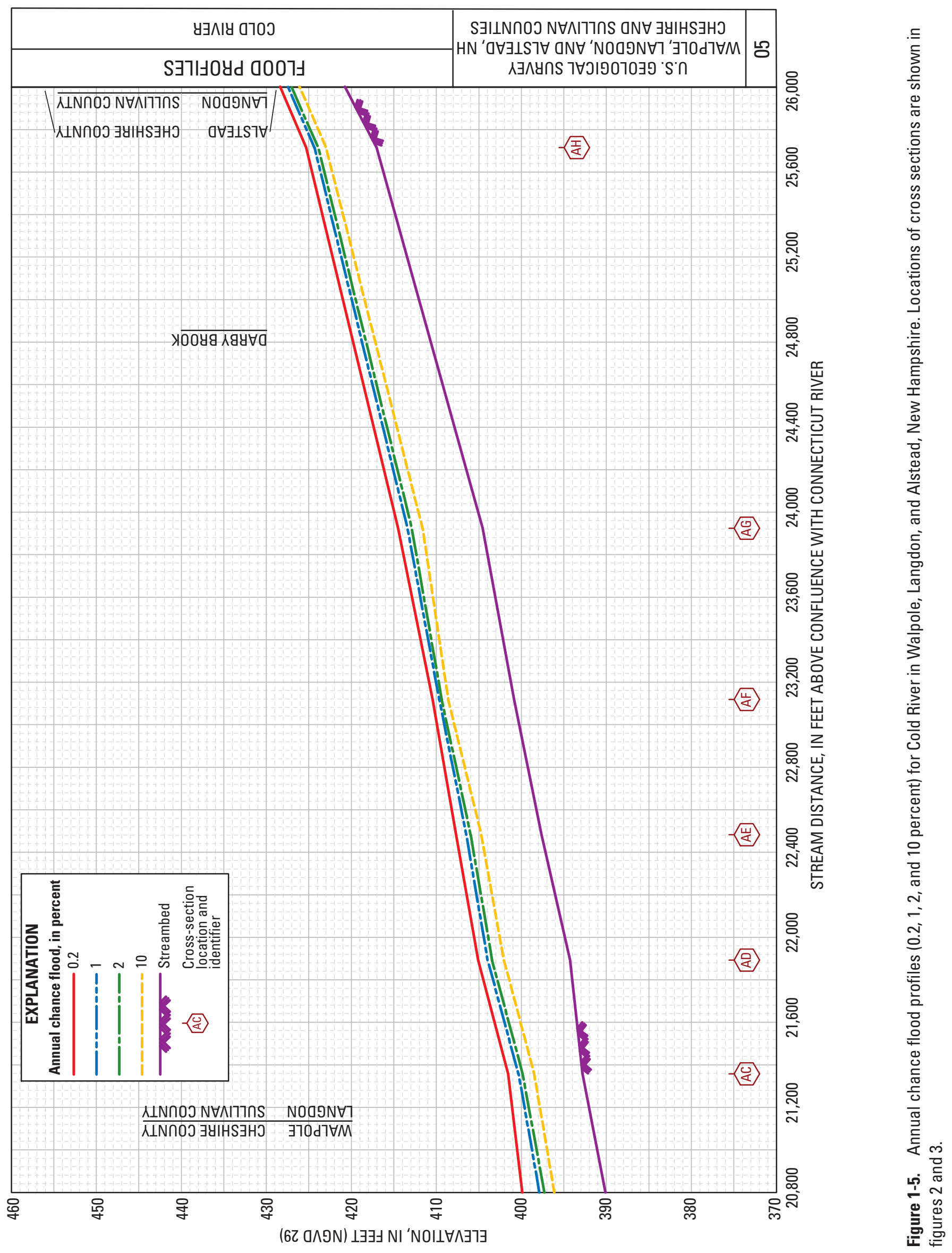




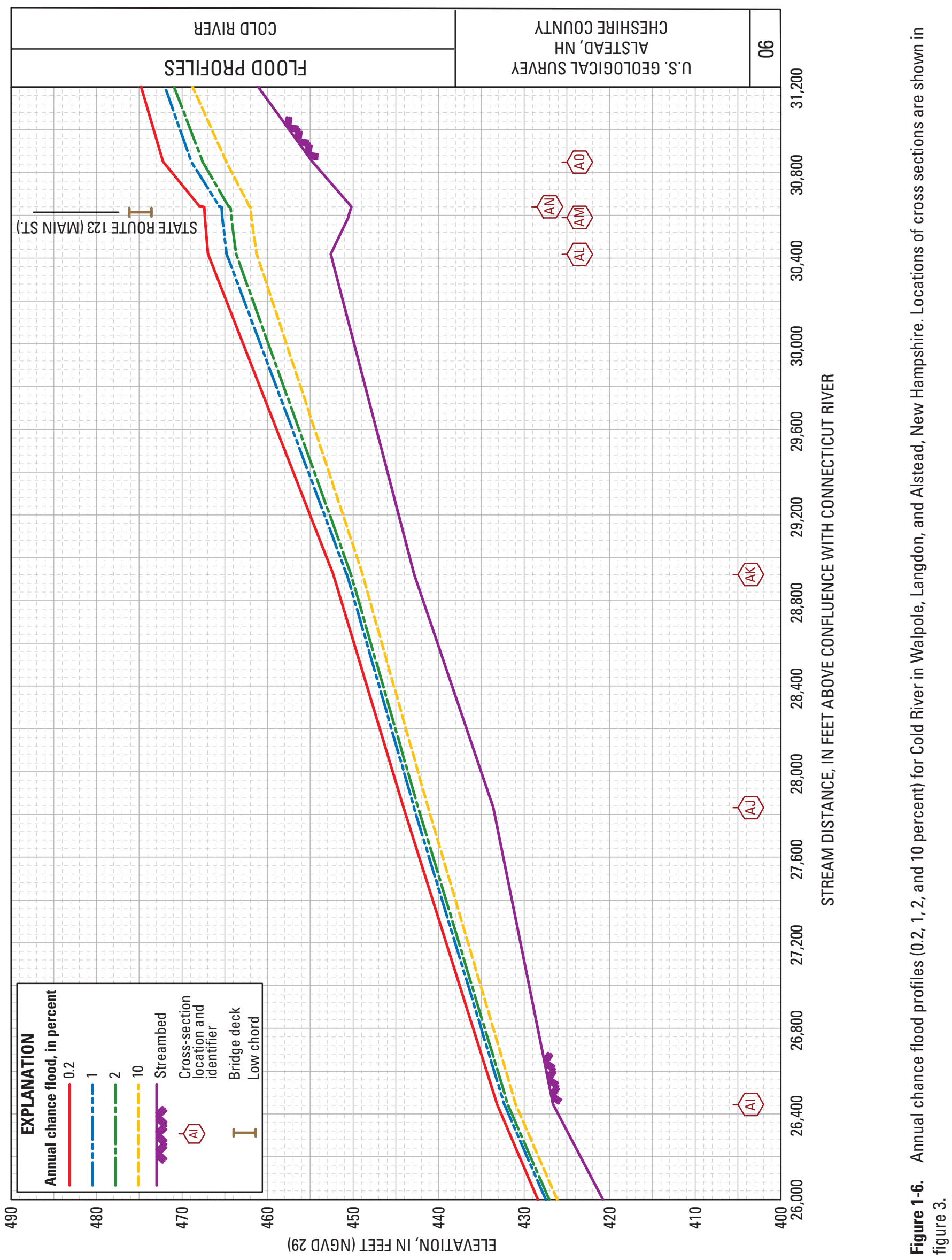




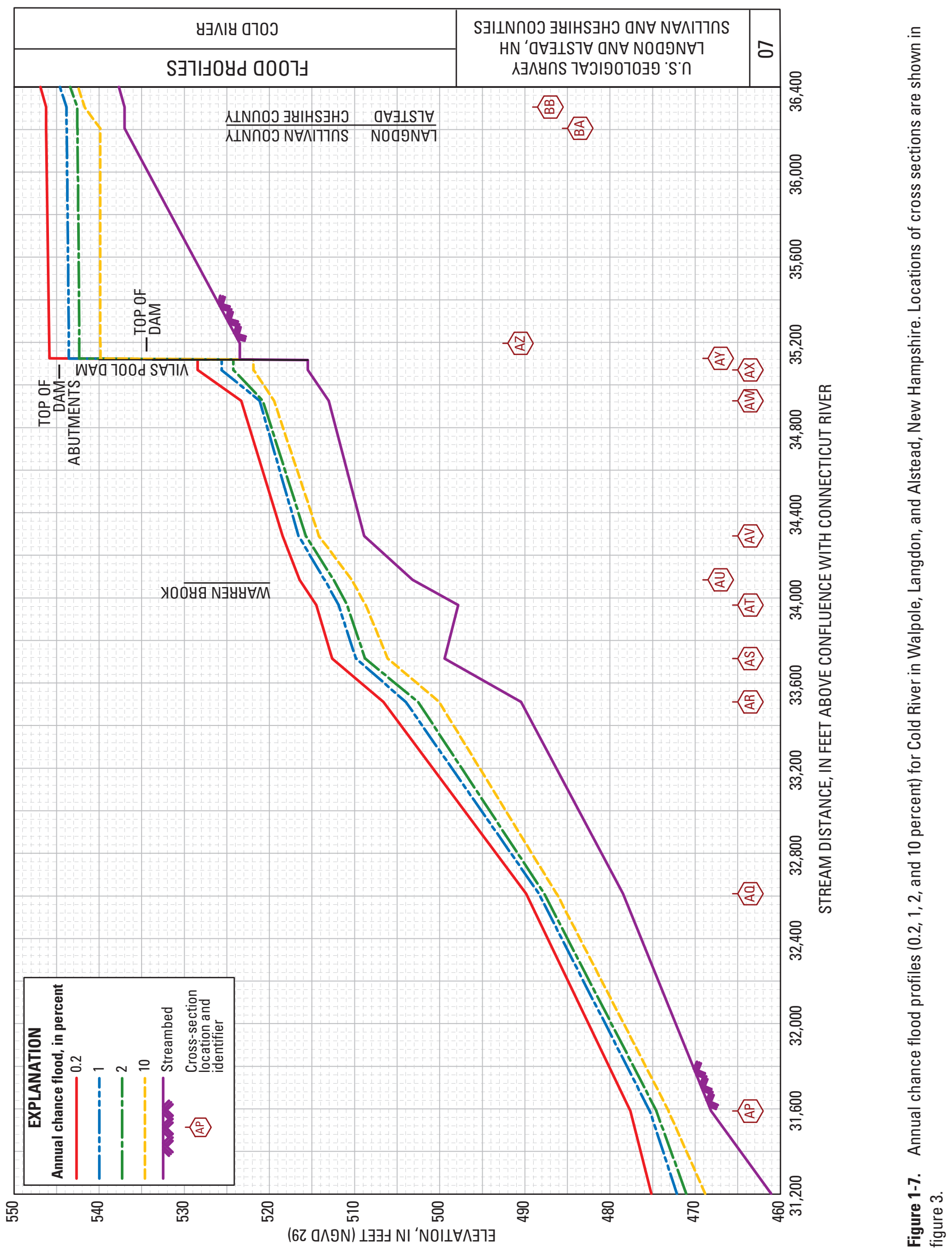




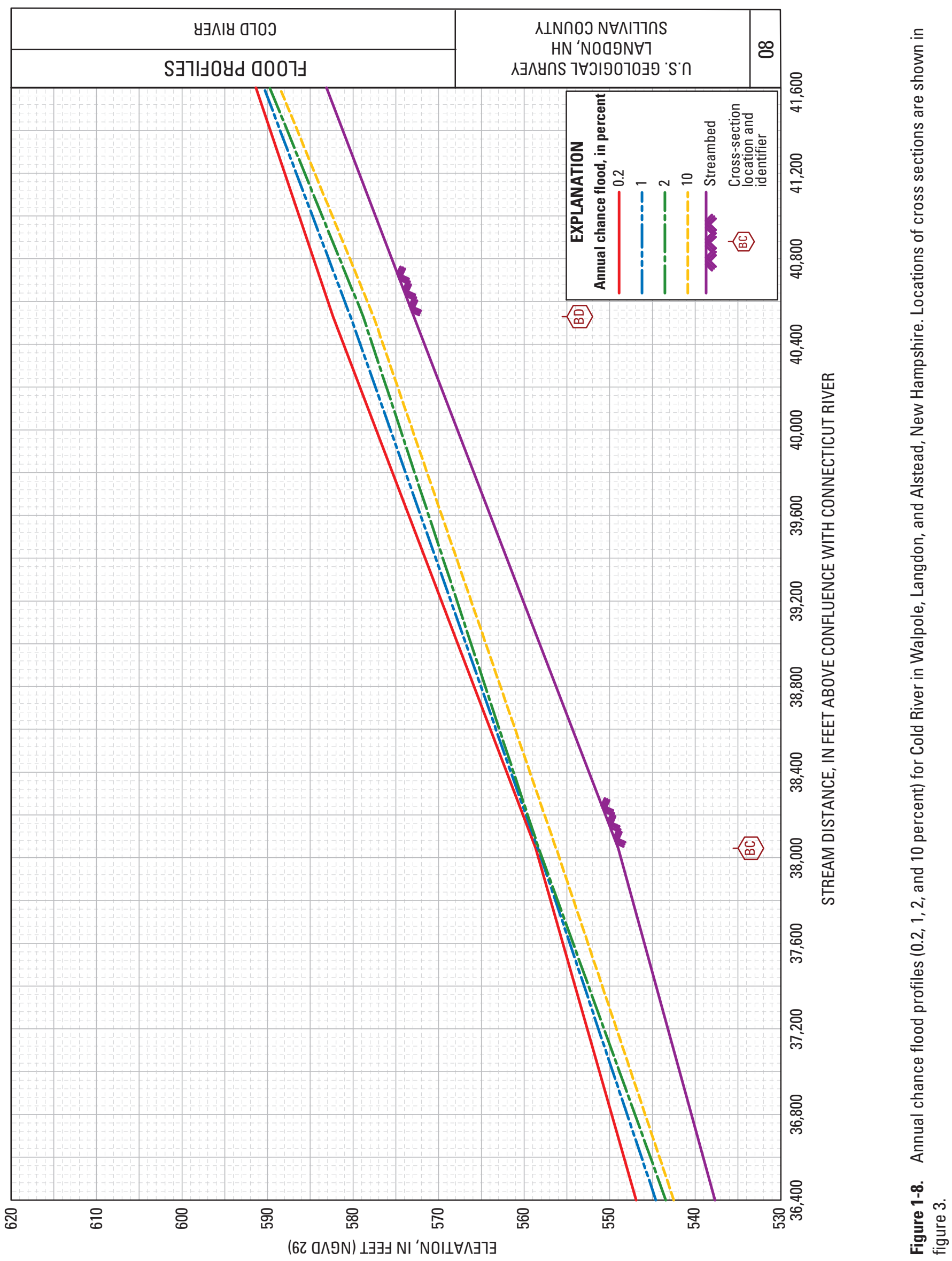




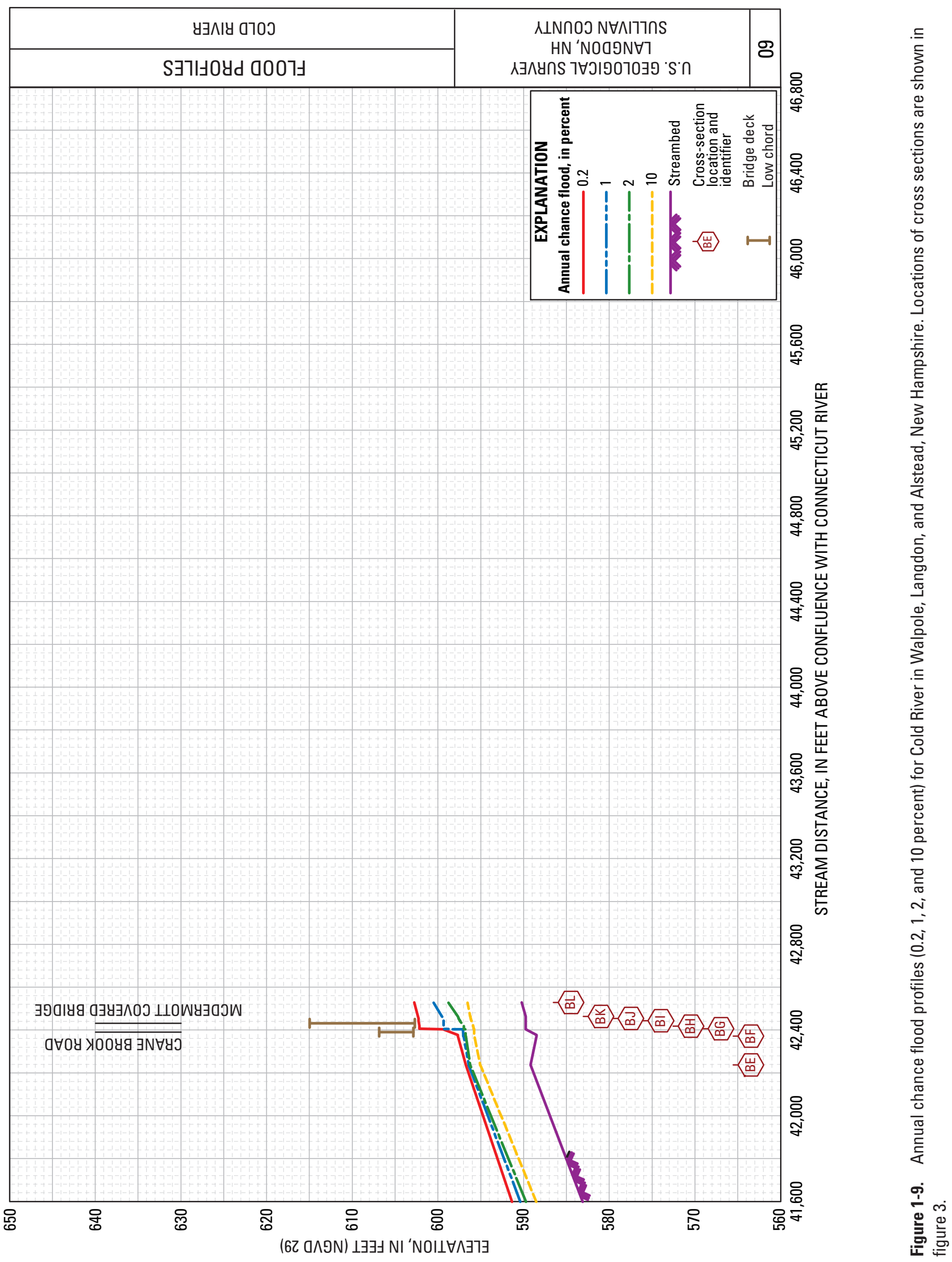




\section{Appendix 2: Warren Brook Flood Profiles}




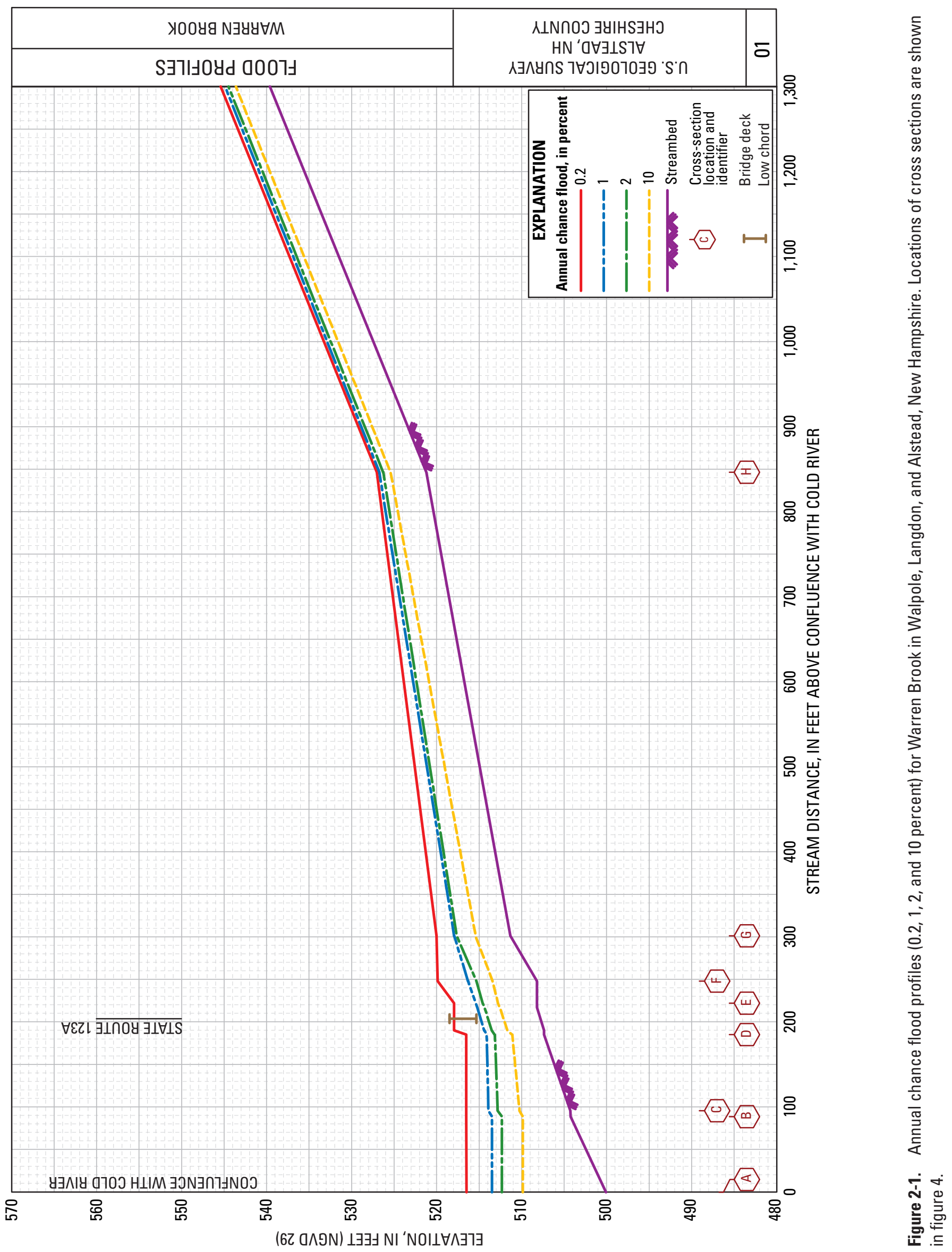




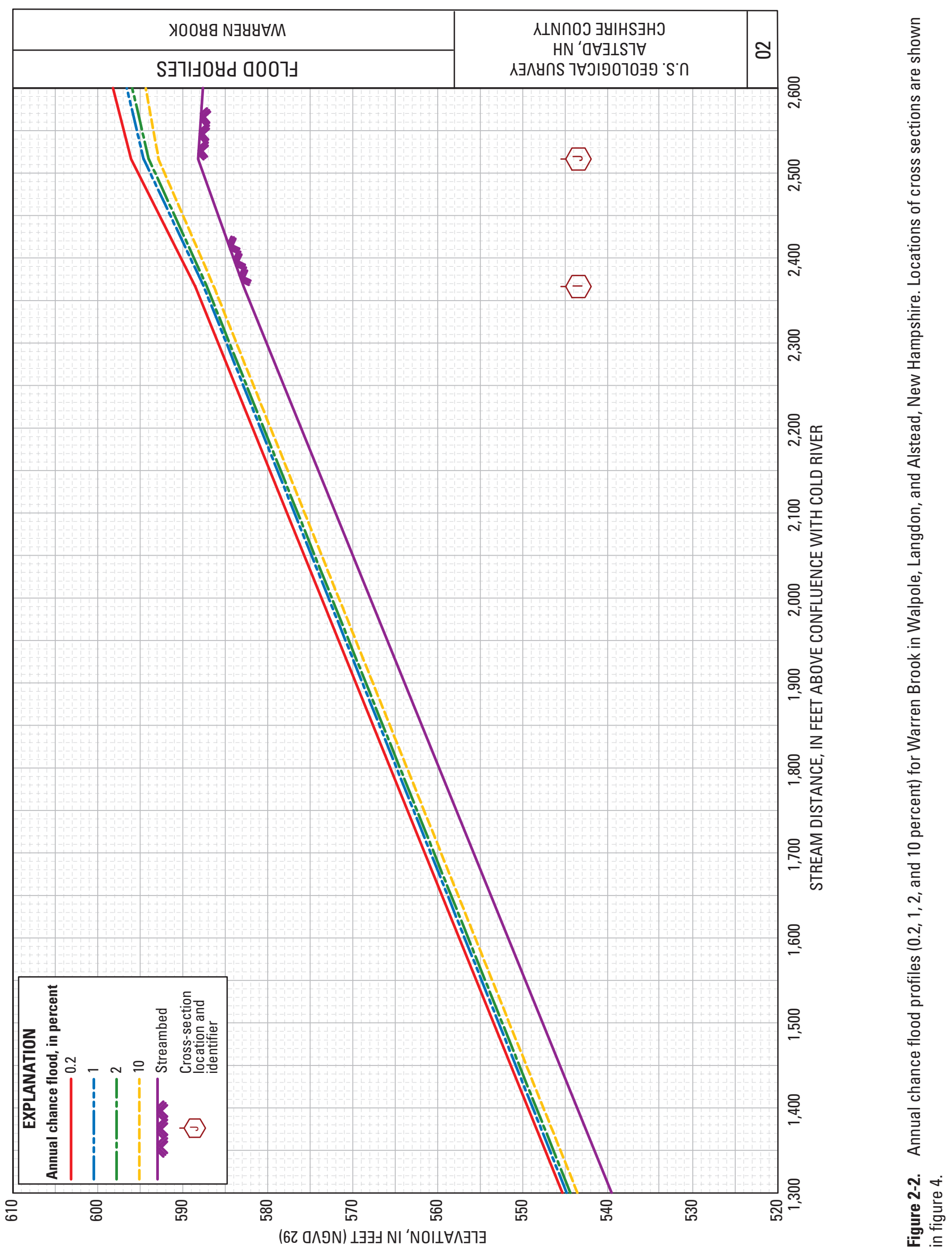




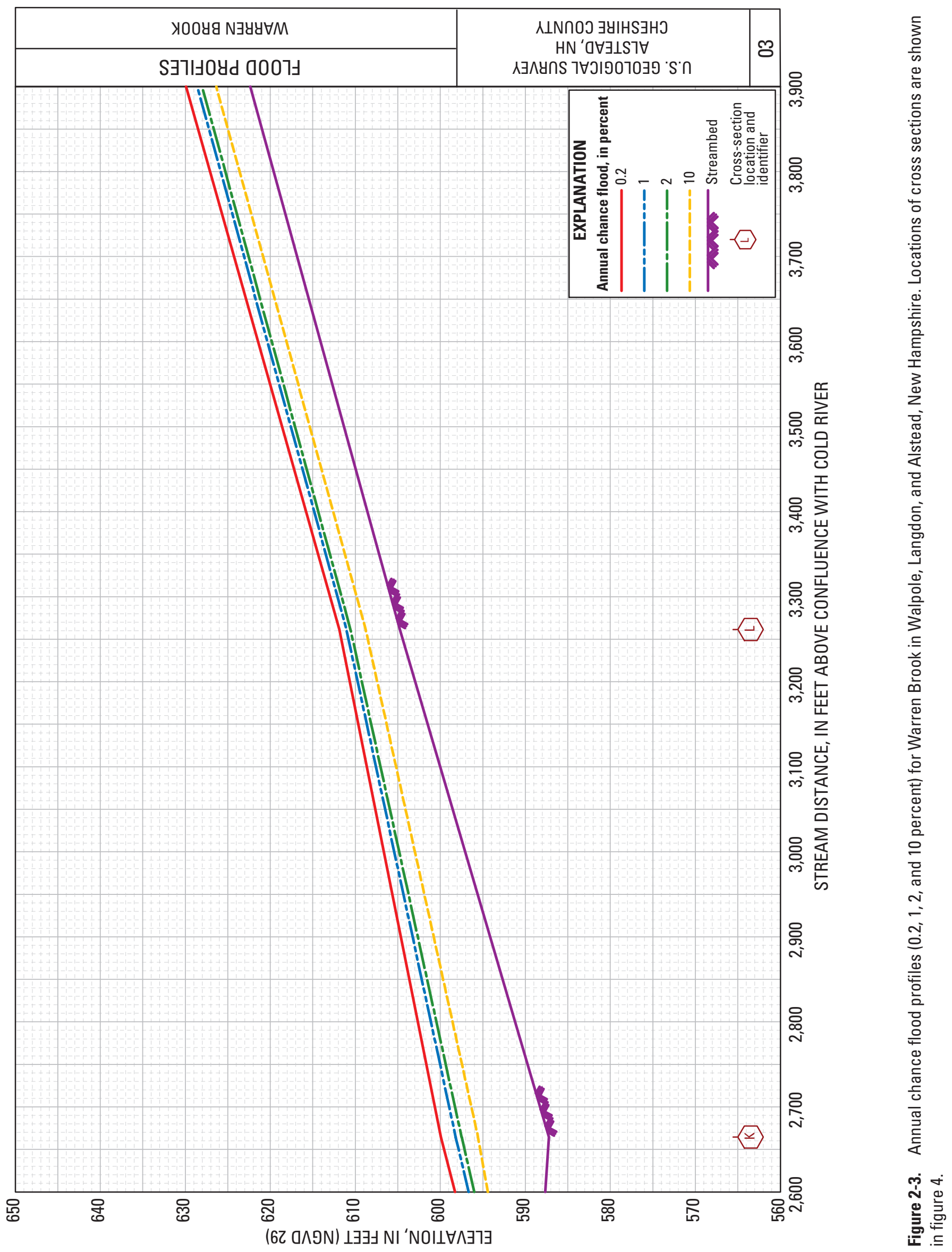




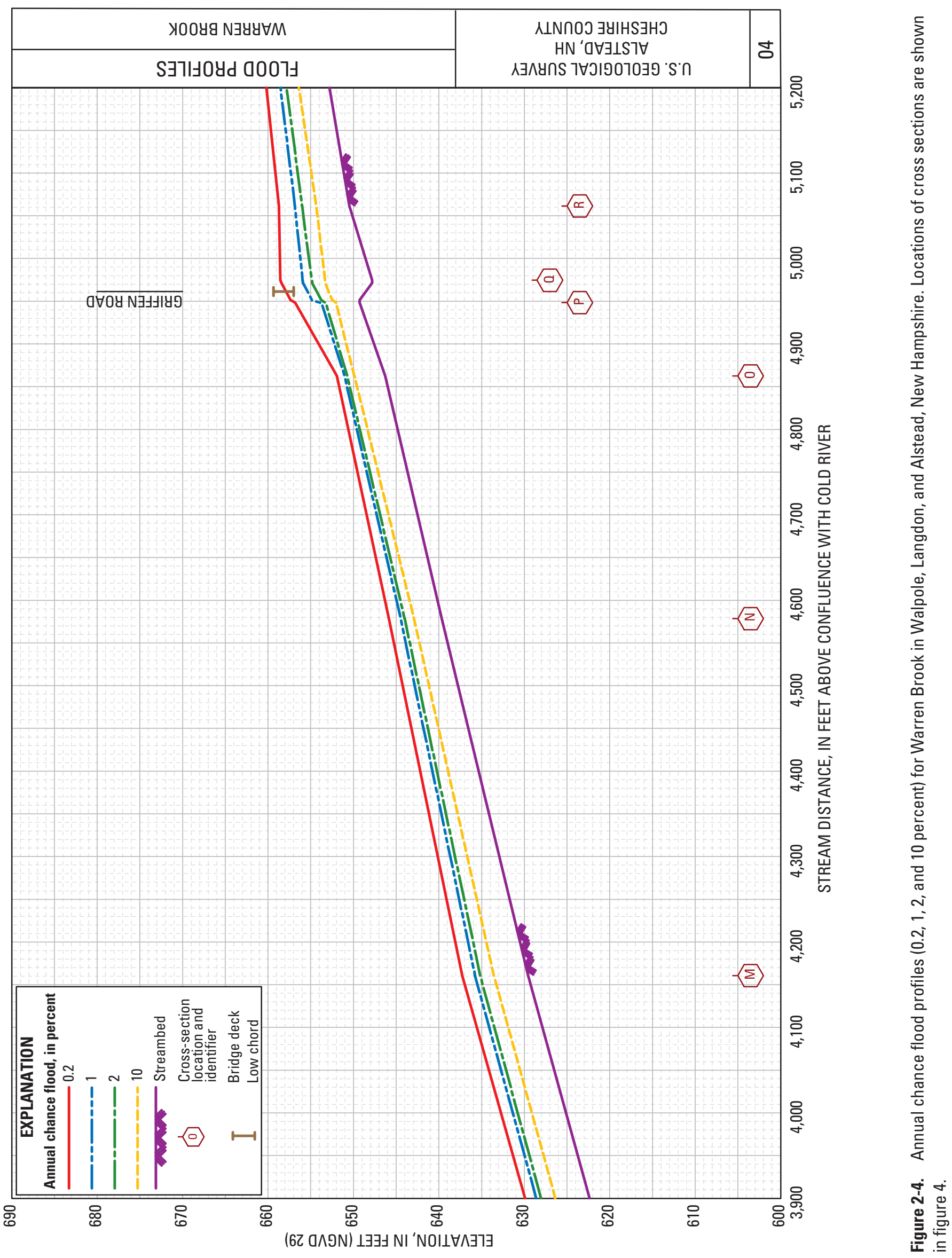




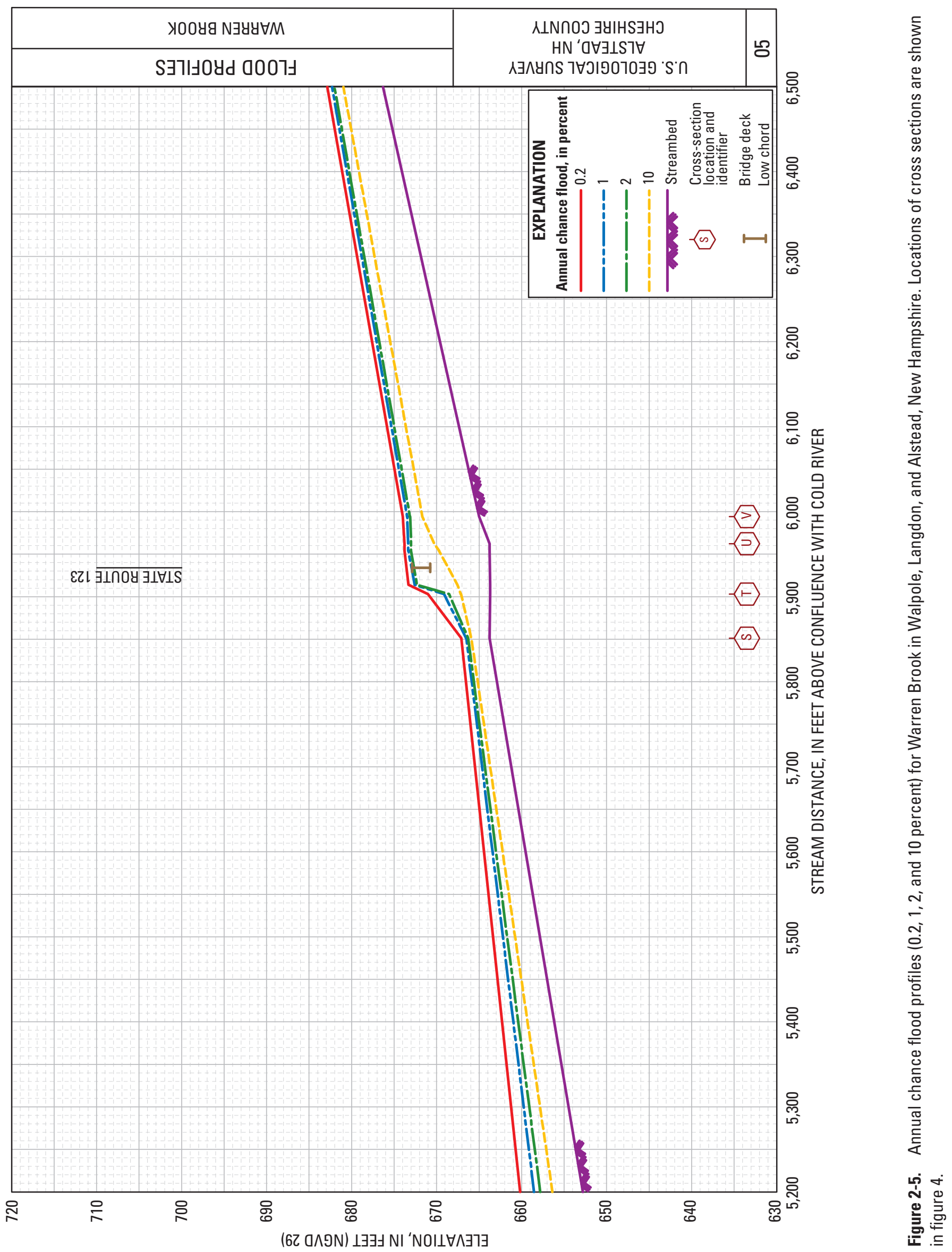




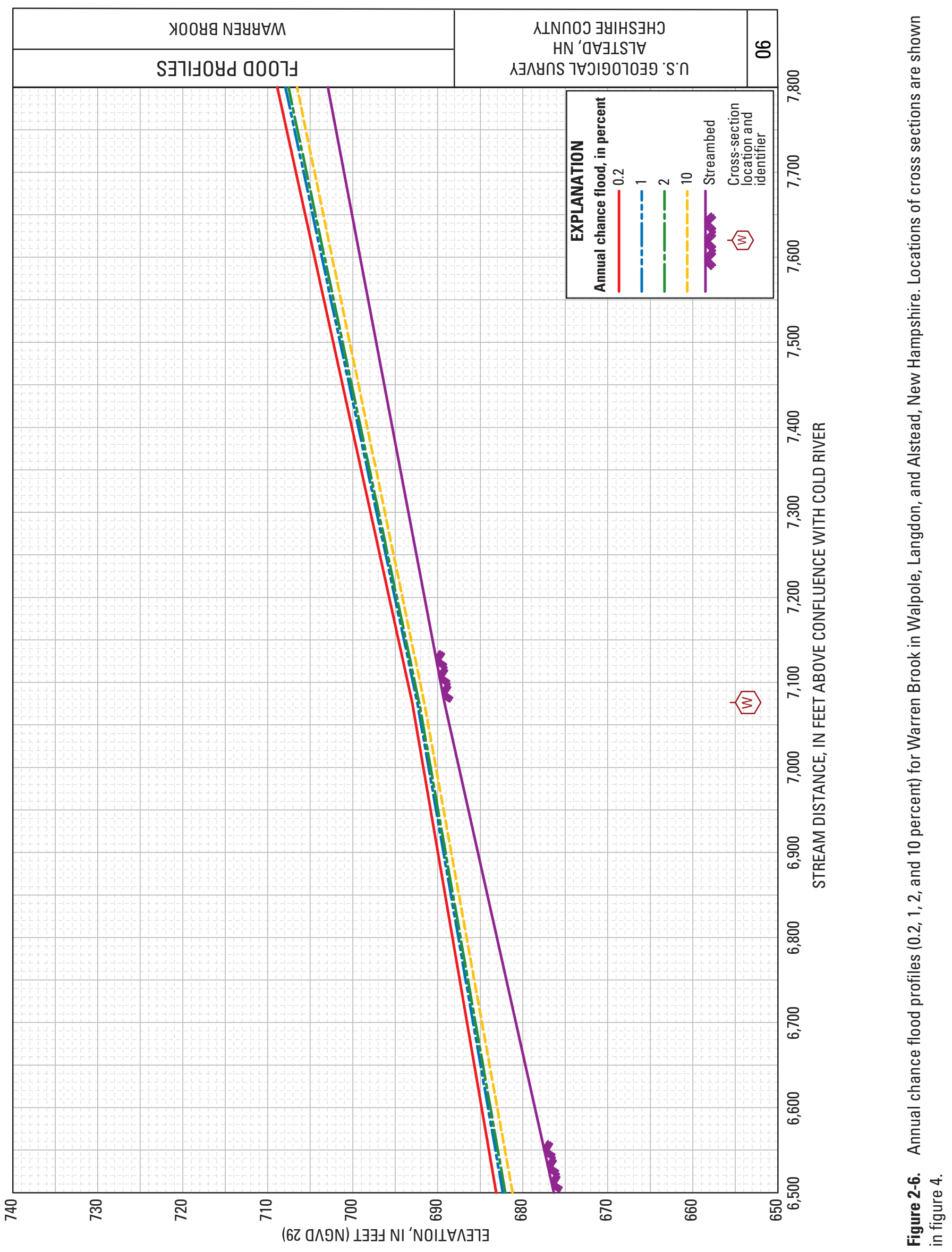




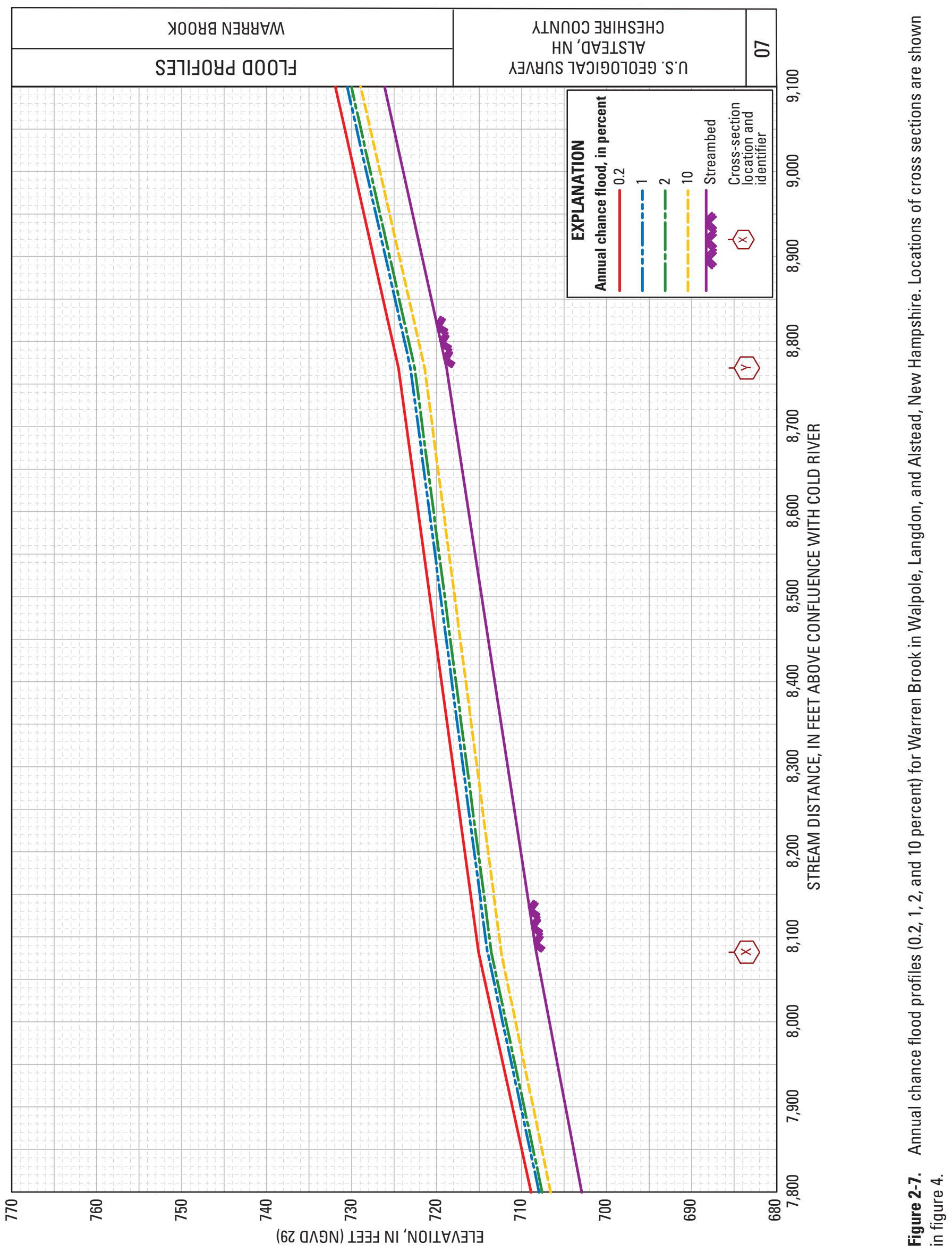




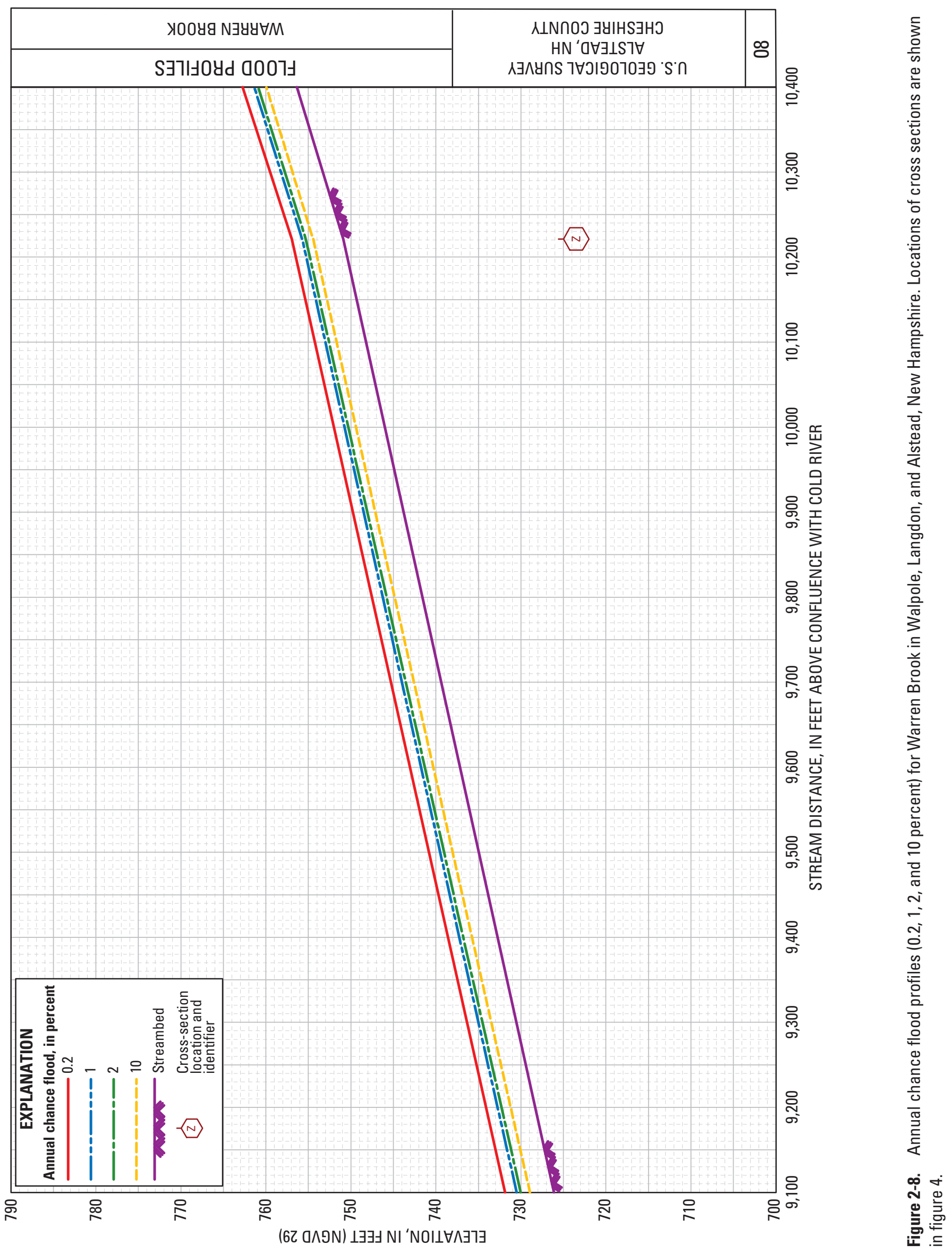




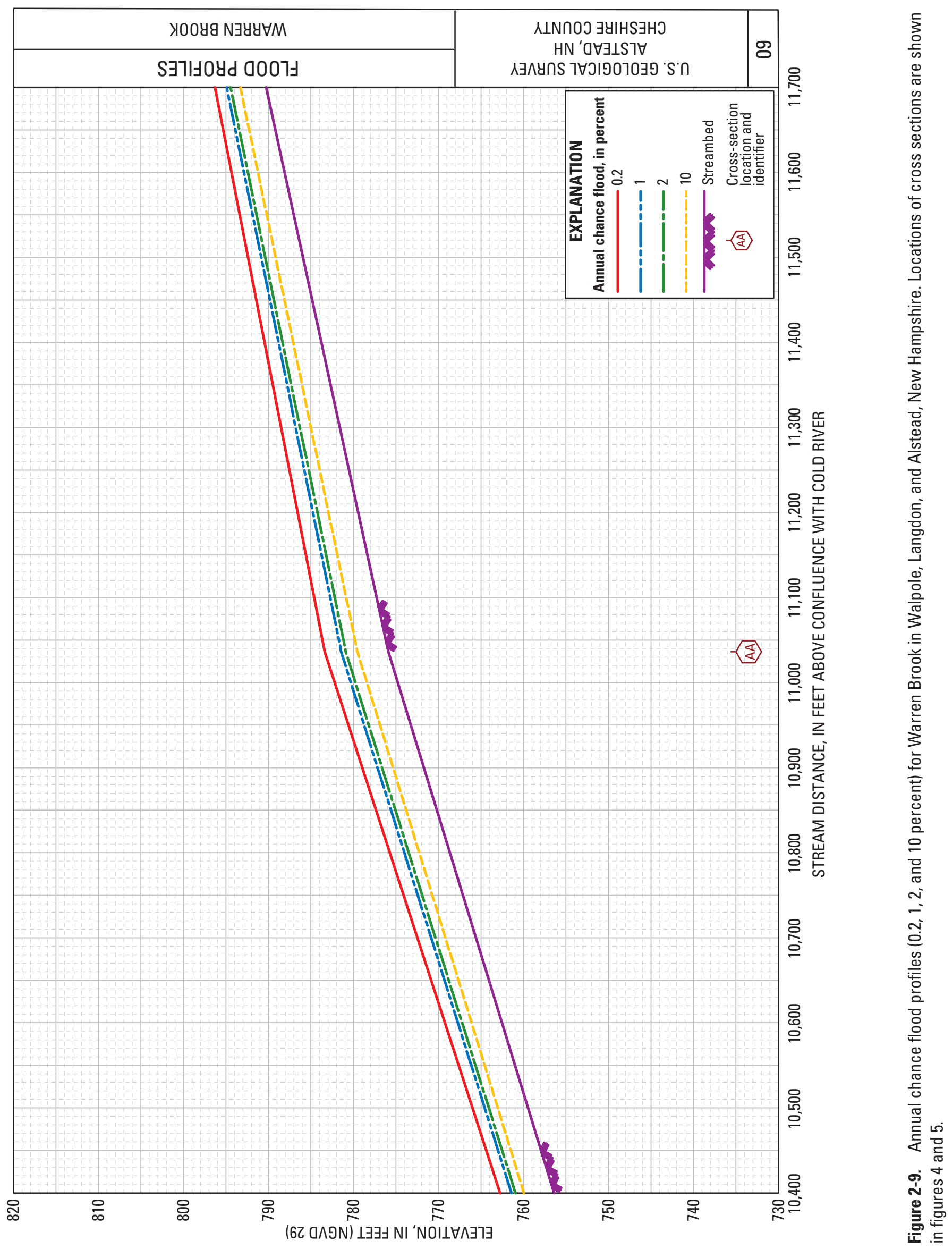




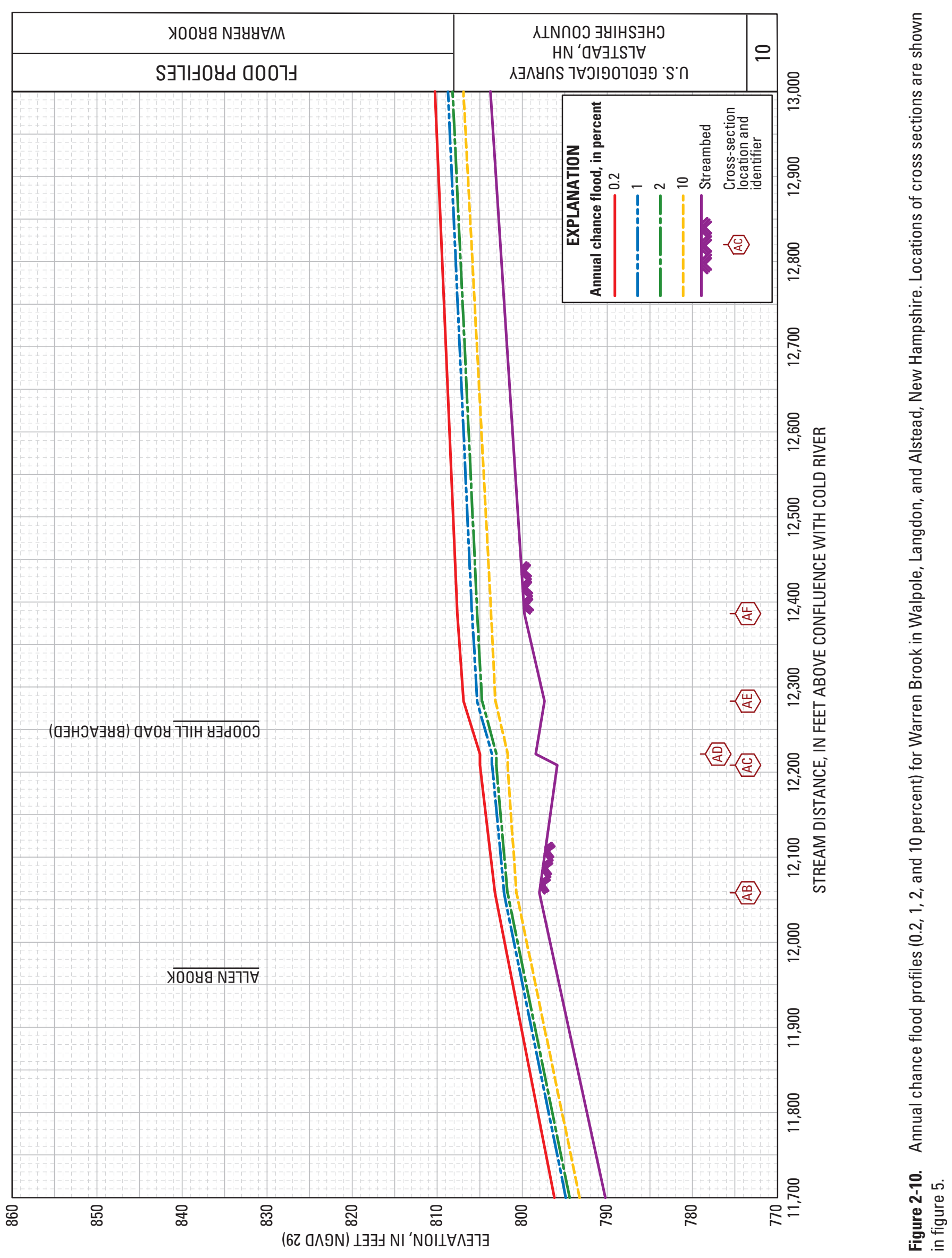




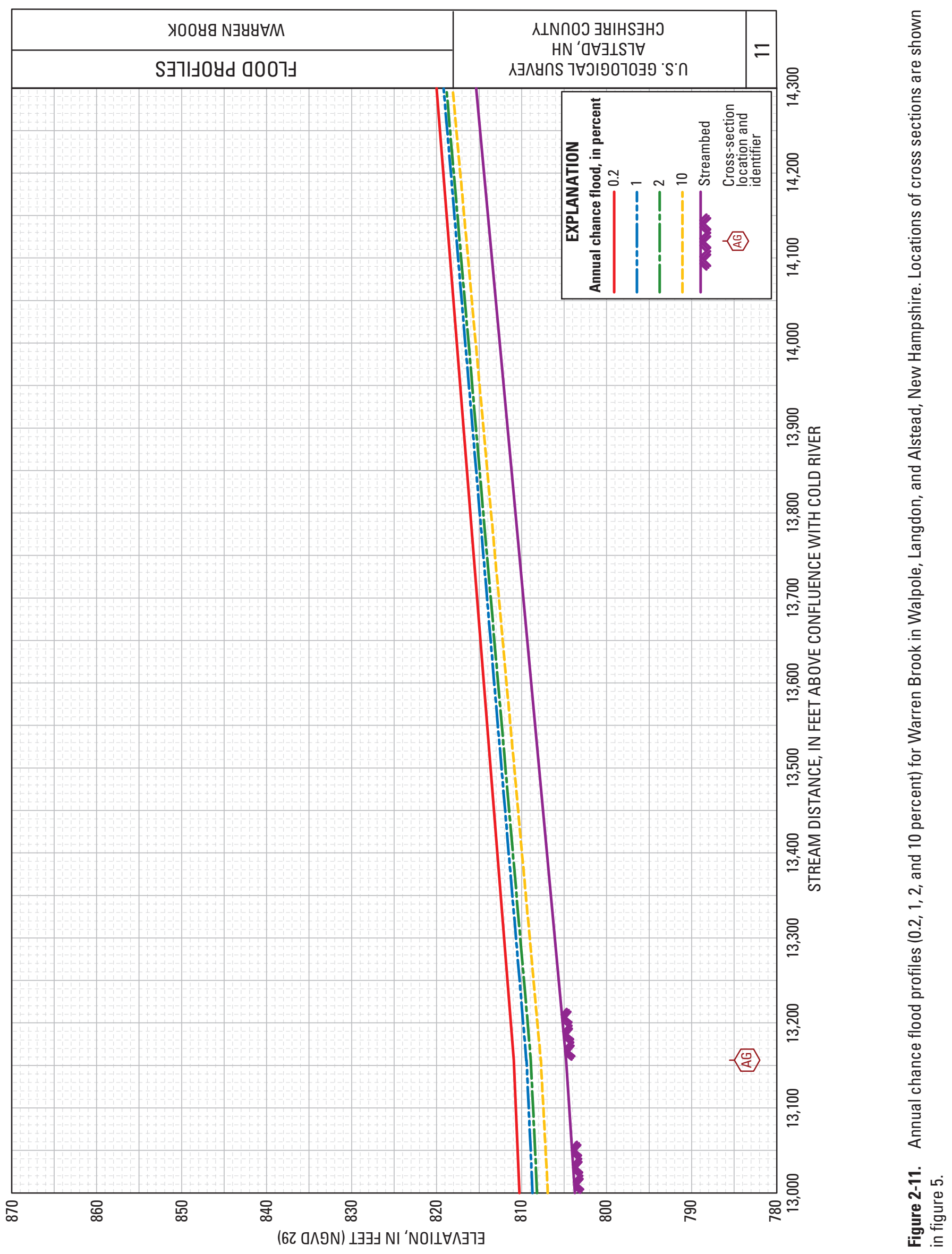




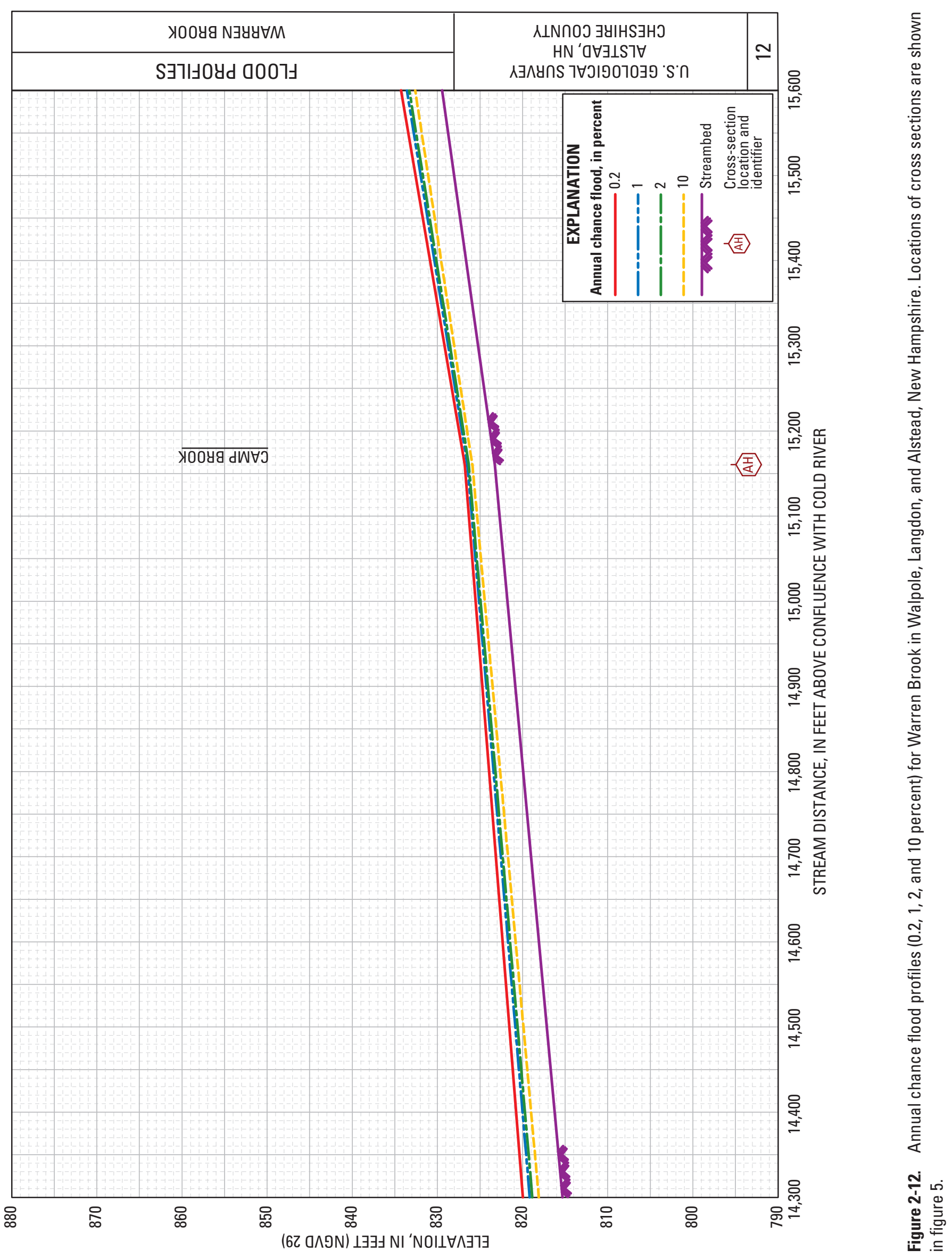




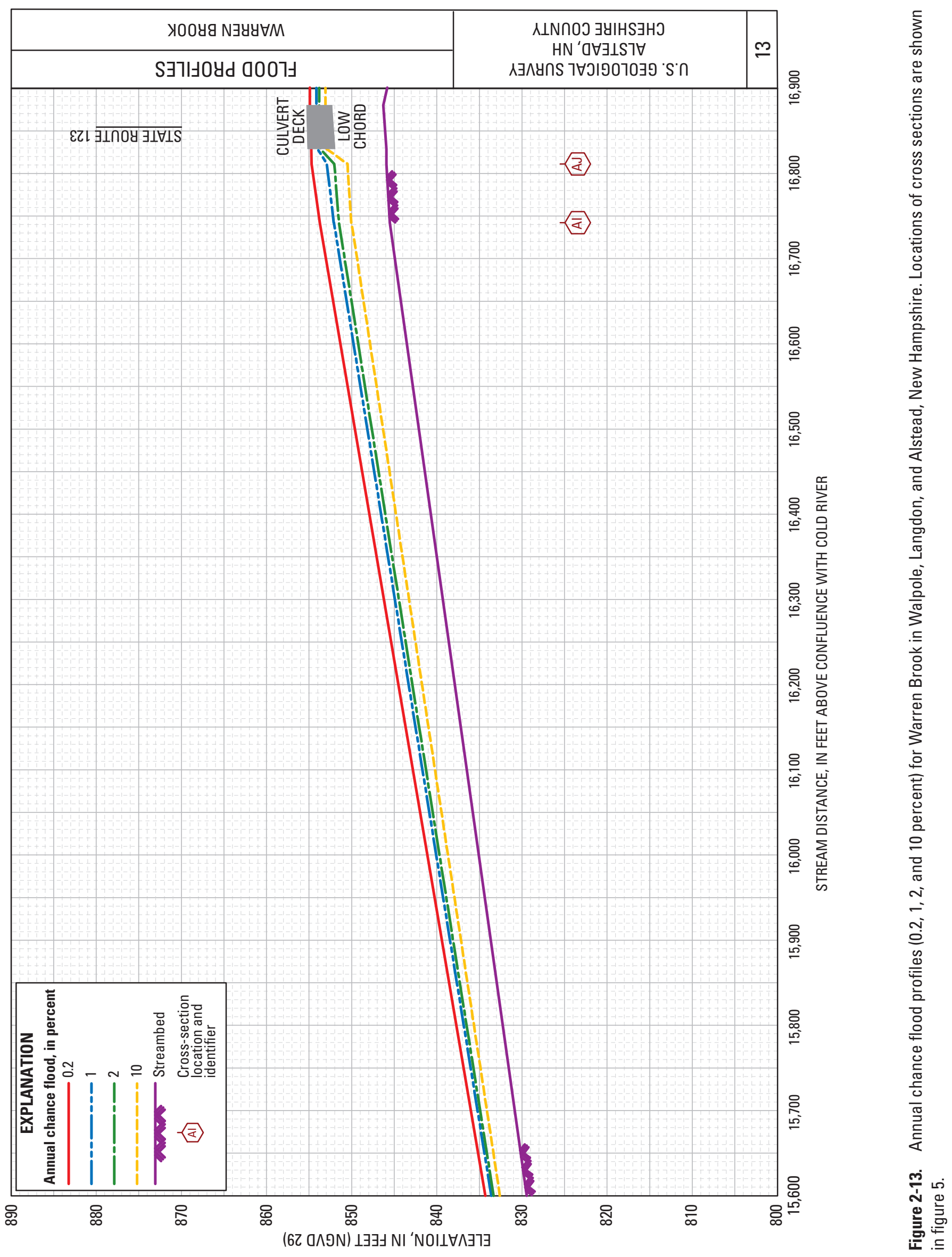




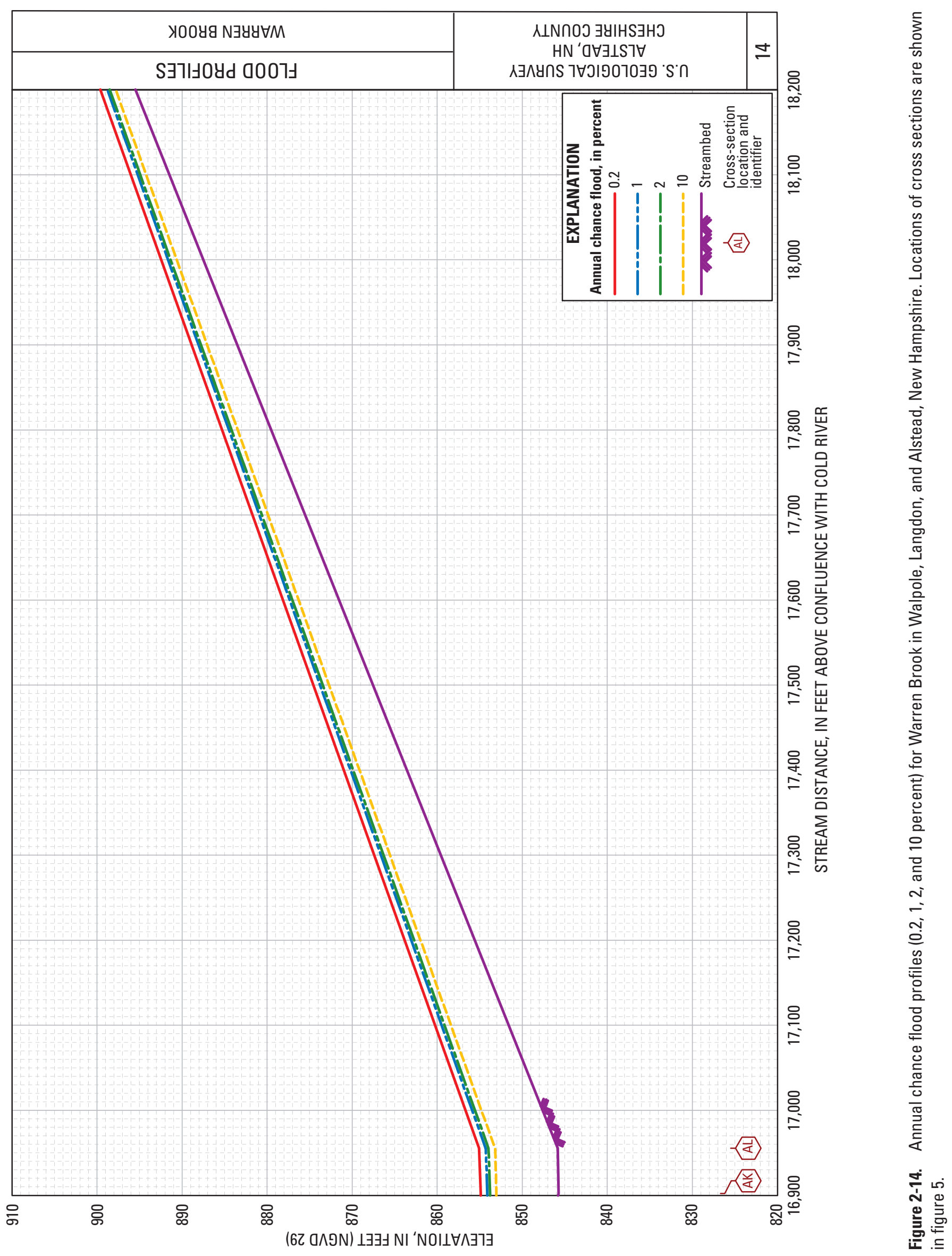




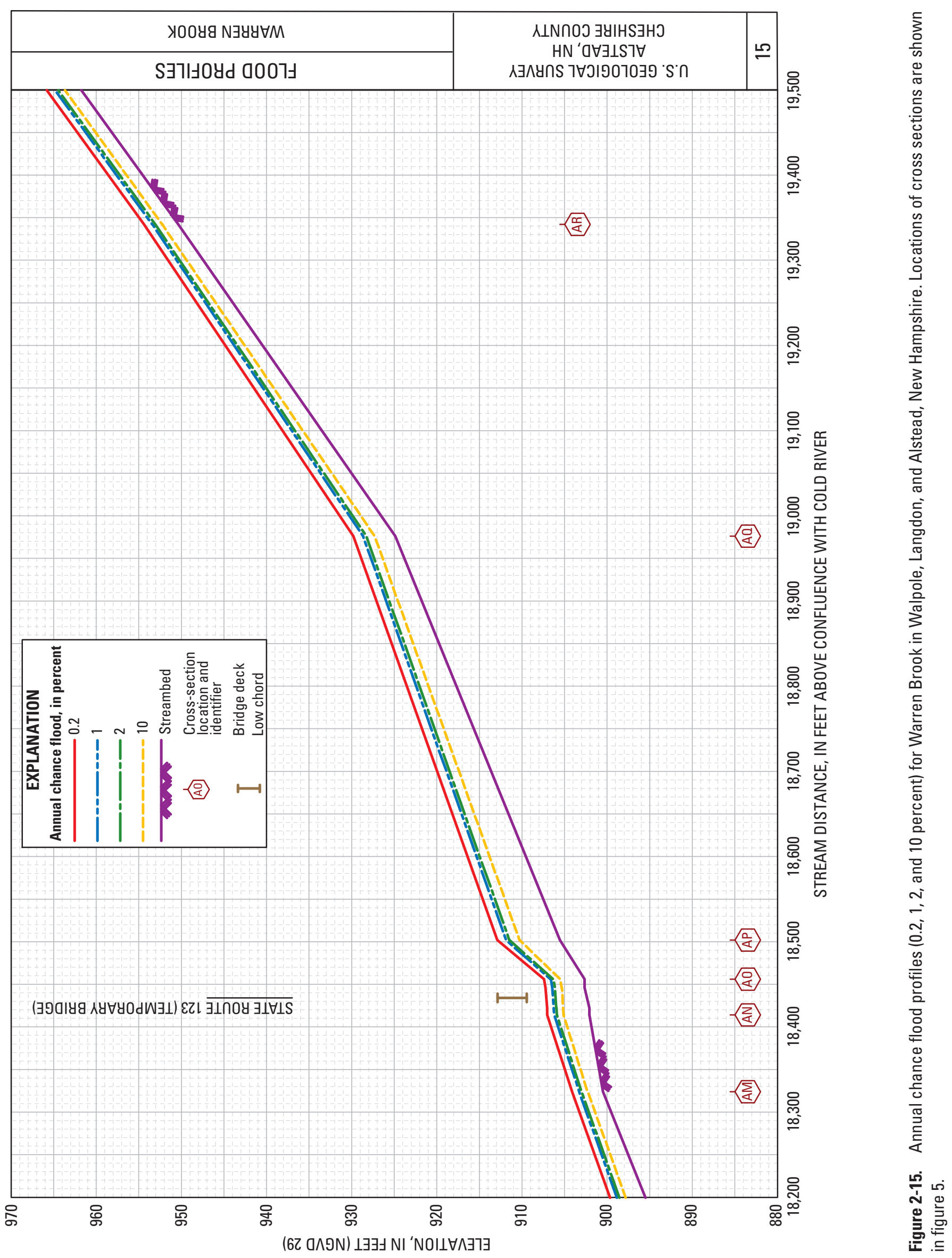




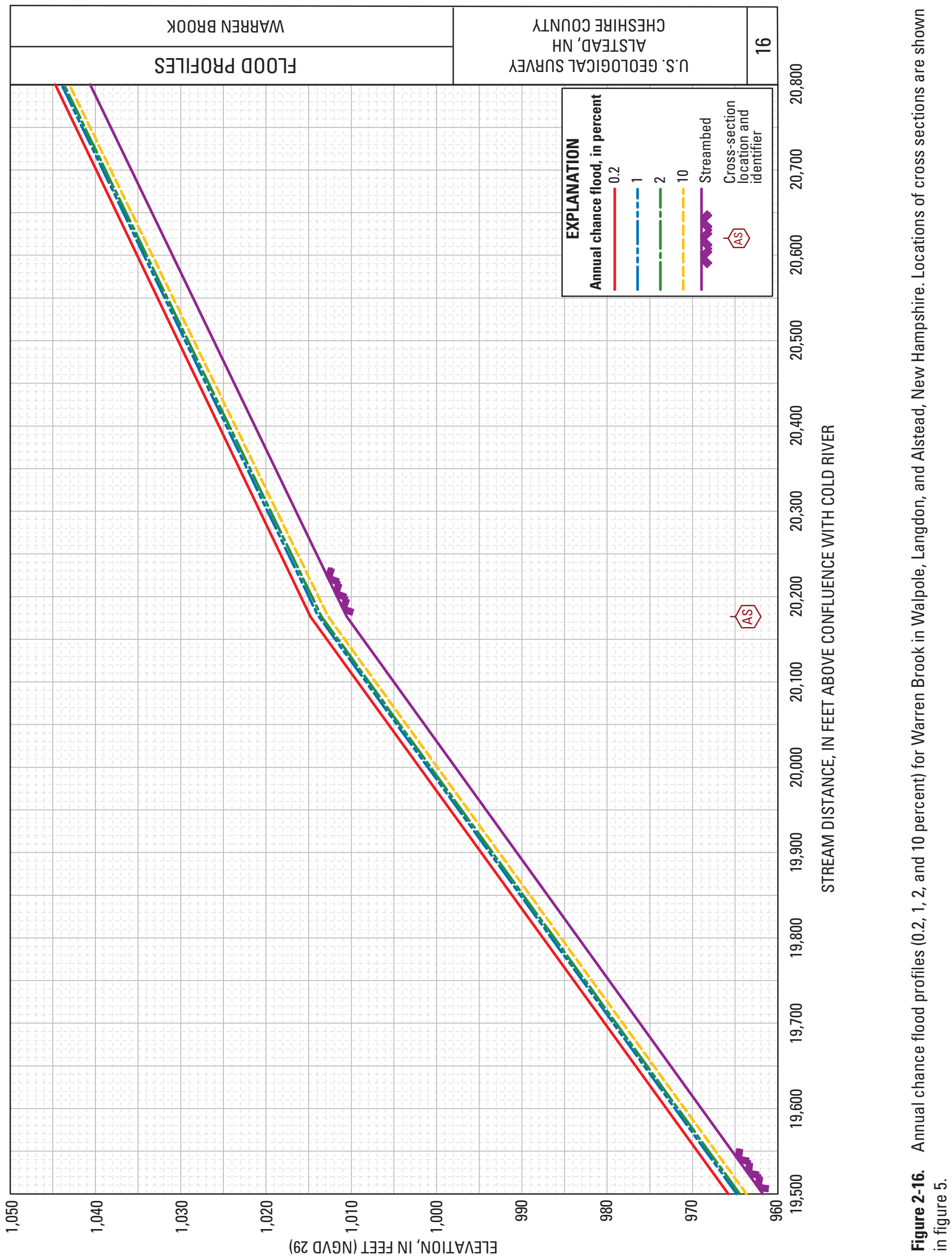




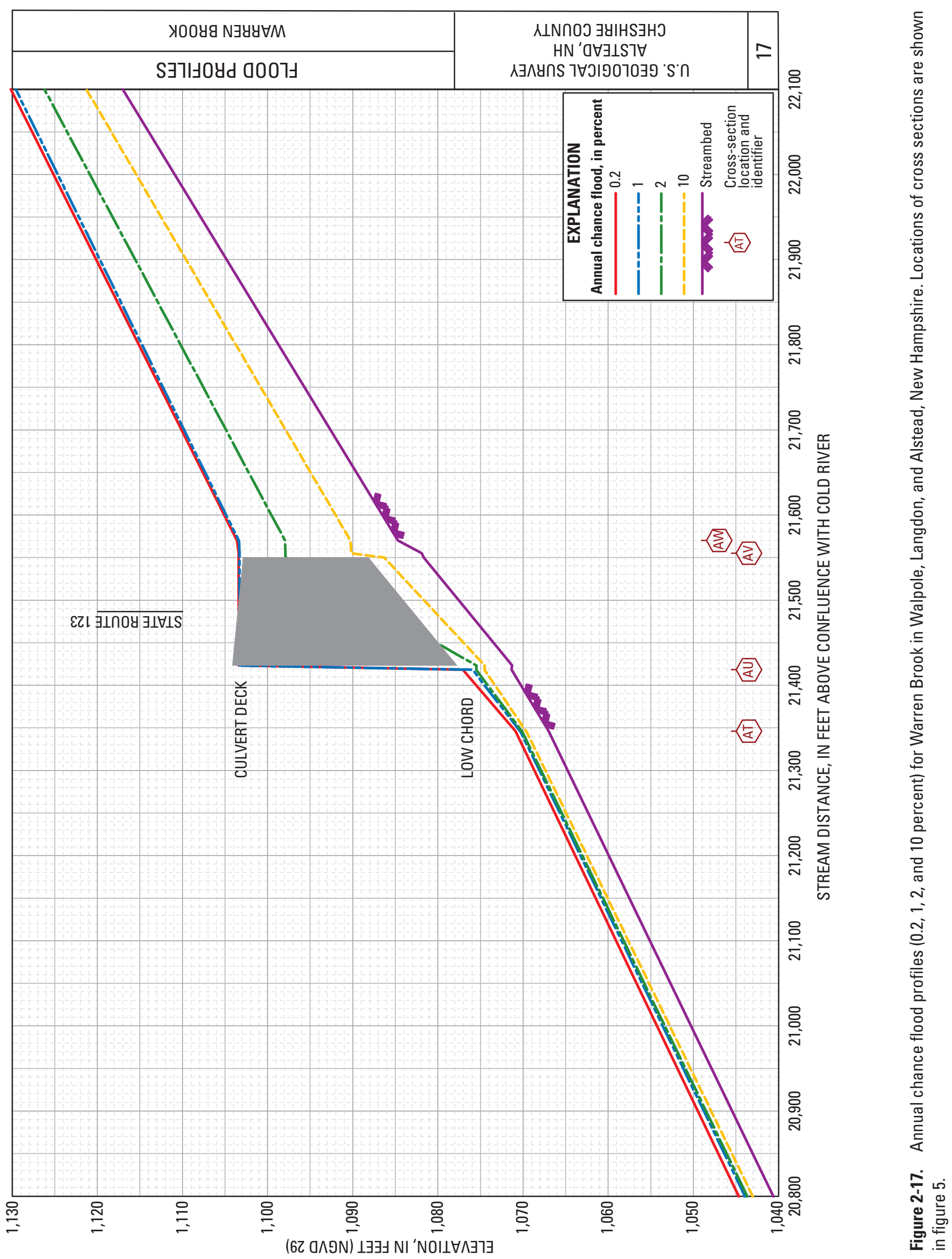




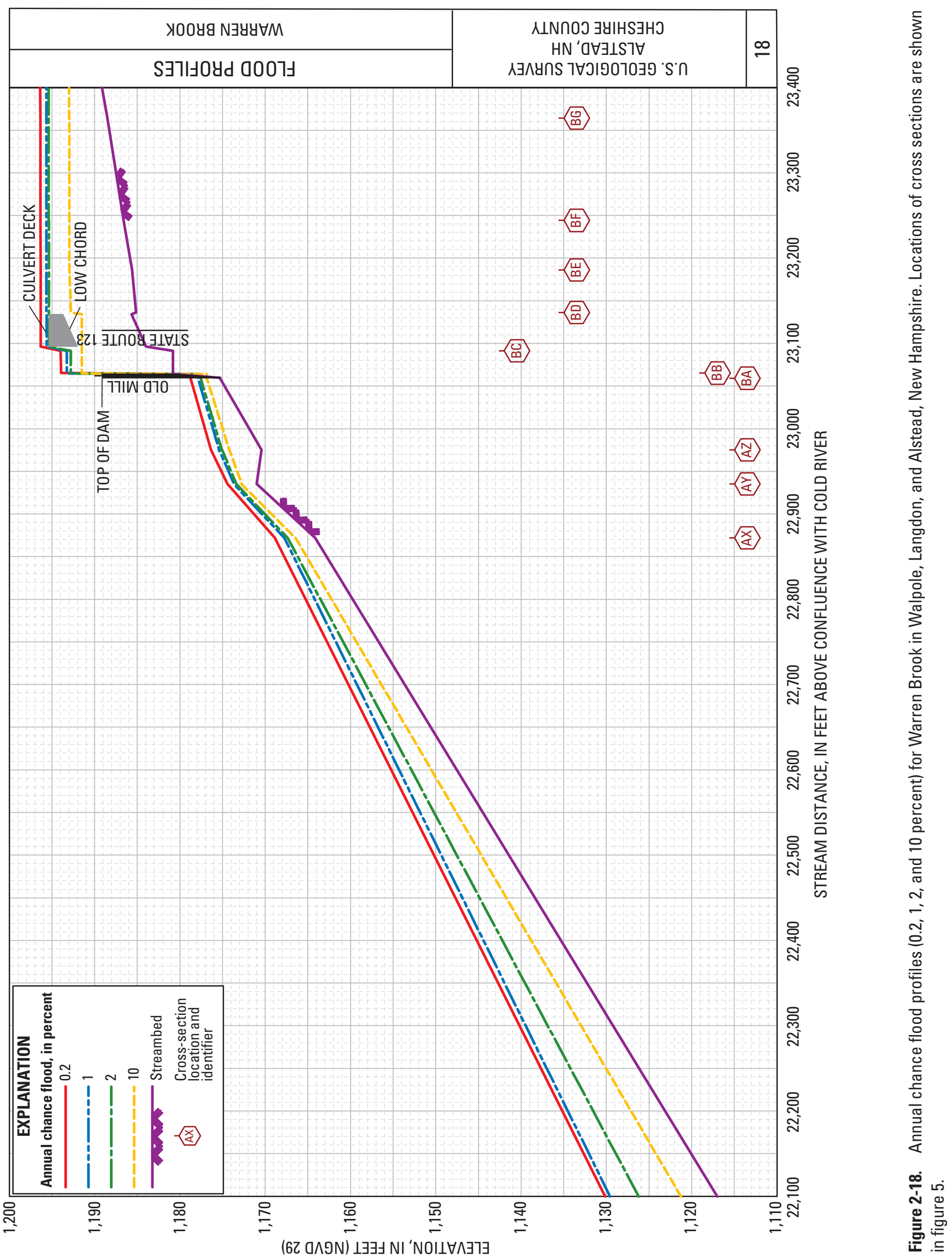




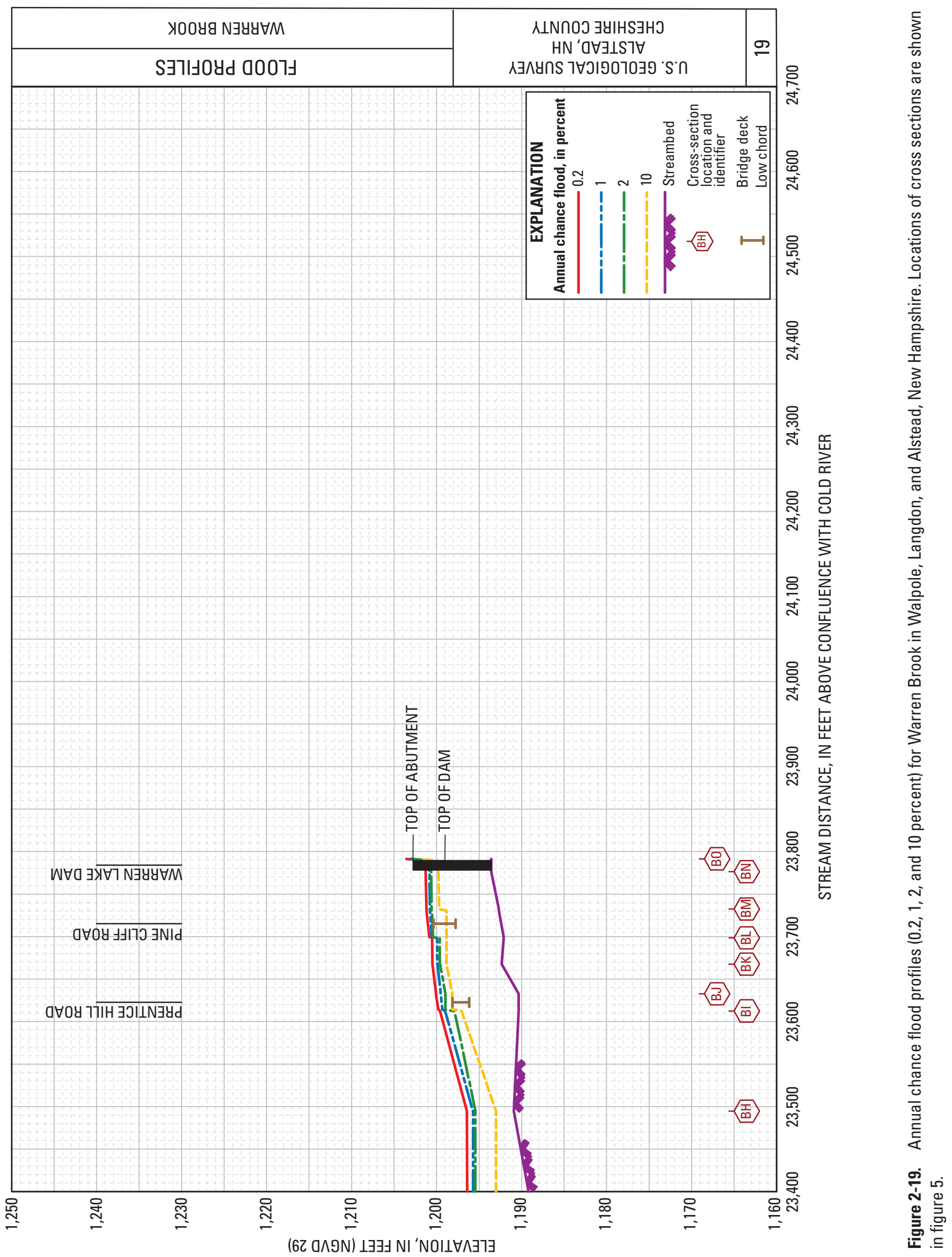




\section{Appendix 3: Elevation Reference Marks}


Information that may be available at the local community map repository before making flood elevation and(or) flood-plain boundary determinations.

Appendix 3. Elevation reference marks.

[ft, foot; NGVD 29, National Geodetic Vertical Datum of 1929; USGS, U.S. Geological Survey]

\begin{tabular}{lcc}
\hline Reference mark & $\begin{array}{c}\text { Elevation } \\
\text { (ft, NGVD 29) }\end{array}$ & Description of location \\
\hline $4611-0100$ & 392.21 & $\begin{array}{c}\text { Standard tablet stamped "461-0100" set in the top of the upstream end of the north abutment of the } \\
\text { Route 123 bridge over the Cold River in Drewsville, NH. (See fig. 2) }\end{array}$ \\
C 22 USGS 1926 & 477.77 & $\begin{array}{c}\text { Standard USGS disk stamped "C 22 1926" and set in the north concrete curb of the grass triangle } \\
\text { formed by the road junction of State Routes 12A and 123 and Hill Road in Alstead. (See fig. 3) }\end{array}$ \\
C 24 USGS 1926 & $1,190.78$ & $\begin{array}{c}\text { Standard USGS disk stamped "C 24 1926" and set in a concrete dam and foundation to an old } \\
\text { (1767) grist mill, 40 ft north of the center of State Route 123 and 525 ft northwest of the outlet of } \\
\text { Warren Lake. (See fig. 5) }\end{array}$ \\
\hline
\end{tabular}


For more information concerning the research in this report, contact: Keith W. Robinson, Director

U.S. Geological Survey

New Hampshire-Vermont Water Science Center

361 Commerce Way

Pembroke, NH 03275

or visit our Web site at:

http://nh.water.usgs.gov 
